\title{
Modulators of Transient Receptor Potential (TRP) Channels as Therapeutic Options in Lung Disease
}

\author{
Alexander Dietrich $(\mathbb{D}$ \\ Walther-Straub-Institute of Pharmacology and Toxicology, Member of the German Center for Lung \\ Research (DZL), LMU Munich, Nussbaumstr. 26, D-80336 Munich, Germany; \\ Alexander.Dietrich@lrz.uni-muenchen.de; Tel.: +49-89-2180-73802
}

Received: 15 January 2019; Accepted: 29 January 2019; Published: 1 February 2019

\begin{abstract}
The lungs are essential for gas exchange and serve as the gateways of our body to the external environment. They are easily accessible for drugs from both sides, the airways and the vasculature. Recent literature provides evidence for a role of Transient Receptor Potential (TRP) channels as chemosensors and essential members of signal transduction cascades in stress-induced cellular responses. This review will focus on TRP channels (TRPA1, TRPC6, TRPV1, and TRPV4), predominantly expressed in non-neuronal lung tissues and their involvement in pathways associated with diseases like asthma, cystic fibrosis, chronic obstructive pulmonary disease (COPD), lung fibrosis, and edema formation. Recently identified specific modulators of these channels and their potential as new therapeutic options as well as strategies for a causal treatment based on the mechanistic understanding of molecular events will also be evaluated.
\end{abstract}

Keywords: non-neuronal; transient receptor potential (TRP) channels; TRPA1; TRPC6; TRPV1; TRPV4; lung; asthma; cystic fibrosis; lung fibrosis; lung edema; chronic obstructive pulmonary disease (COPD)

\section{Introduction}

Our lungs are not only essential for gas exchange but are also exposed to the external environment. Therefore, we inhale toxicants, allergens, and infectious agents like bacteria, viruses, and fungi together with vitally important oxygen. The airways of our lungs are composed of bronchi, which branch many times into smaller airways ending in narrow bronchioles. At the end of each bronchiole are thousands of small air sacs, called alveoli, where the gas exchange with the circulating blood takes place. In the upper airways, ciliated epithelium together with mucus producing goblet cells try to extrude foreign particles supported by the cough reflex, which is triggered by activation of sensory nerve endings [1]. In the alveoli, thin aveolar type 1 (AT1) epithelial cells ensure efficient gas exchange, while square-sized alveolar epithelial cells type 2 (AT2) produce surfactant protein to reduce surface tension and to serve as an additional barrier. Moreover, AT2 cells are able to differentiate to AT1 cells to rebuild the alveolar barrier after acute or chronic injury [2]. Next to the airways, the pulmonary vasculature ensures fast transport of oxygen by erythrocytes to organs in the body replacing $\mathrm{CO}_{2}$, which is exhaled (see Figure 1). Airway epithelium and vascular endothelium offer a most efficient protection of the lung, which will be seriously damaged if cellular functions are clogged. In all these cells and additionally in immune cells circulating in the pulmonary vasculature, members of the superfamily of transient receptor potential (TRP) channels are expressed. These non-selective $\mathrm{Ca}^{2+}$ permeable cation channels at the plasma membrane have multiple functions as chemosensors and essential members of signal transduction cascades triggering cell function in response to stimuli. They are, however, also involved in pathophysiological processes of the lung (like chronic inflammation, fibrosis, and edema). This review article, which is also an update of our former manuscript [3], will focus 
on TRP channels (TRPA1, TRPC6, TRPV1, and TRPV4) predominantly expressed in non-neuronal lung tissues. I will also highlight their specific modulators, which may be important therapeutic options for lung diseases like pulmonary hypertension (PH), asthma, cystic fibrosis (CF), chronic obstructive pulmonary disease (COPD), lung fibrosis, and edema formation in the future. For other TRP channels mainly expressed in neuronal tissues of the airways and their involvement in the cough reflex, please refer two other recent reviews [4-6]. TRP channels as toxicant sensors in the lung are also highlighted in two other recent manuscripts [3,7].

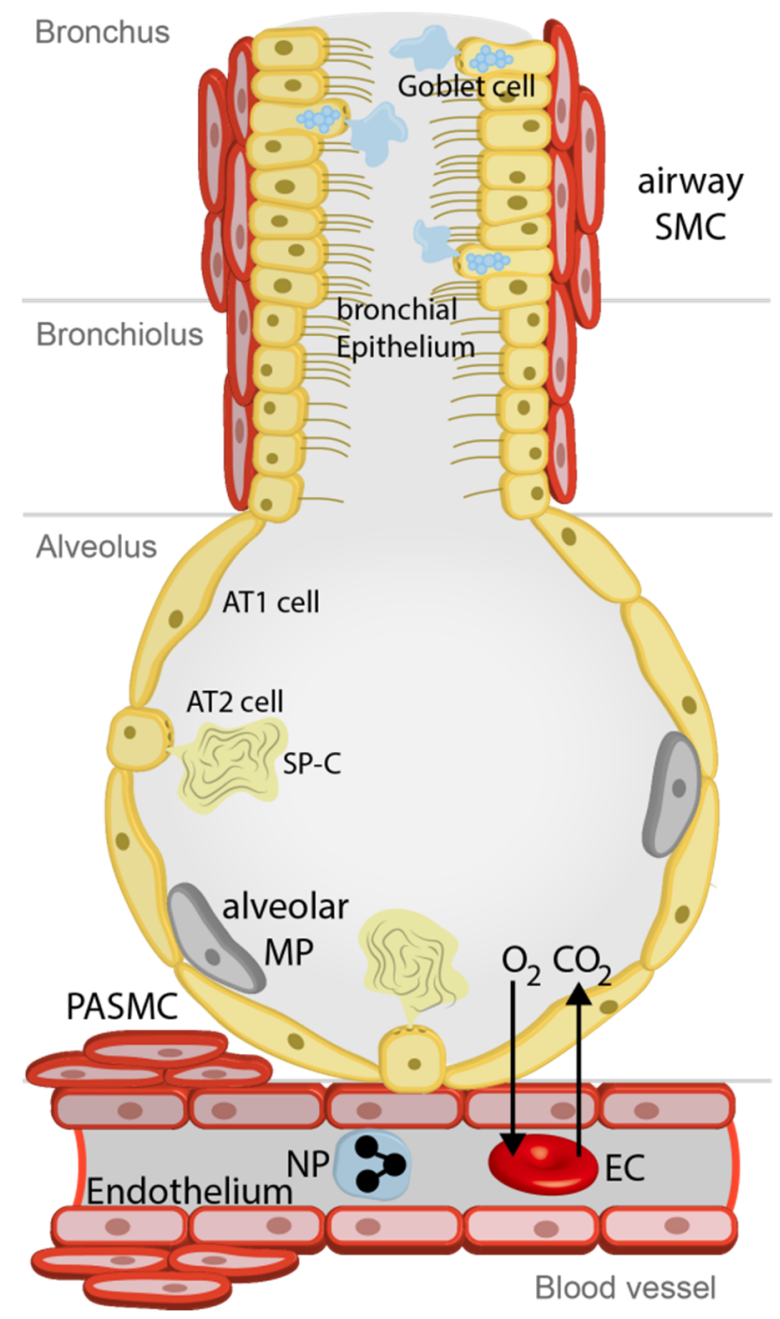

Figure 1. Cells involved in physiological functions of airways and lungs. See text for more details. Airway SMC, airway smooth muscle cells; Alveolar MP, alveolar macrophages; AT1 cells, alveolar type 1 cells; AT2 cells, alveolar type 2 cells; $\mathrm{CO}_{2}$, carbon dioxide; EC, erythro-cyte; $\mathrm{O}_{2}$, oxygen; $\mathrm{NP}$, neutrophil; PASMC, precapillary arterial smooth muscle cells, SP-C, surfactant protein-C.

\section{TRP Expression in Lung Cells, Their Proposed Functions and Specific Regulators}

TRP channels were first described in the fruit fly Drosophila melanogaster after characterization of a mutant with a short-lived depolarizing current as a visual defect termed transient receptor potential (TRP) [8]. This discovery led to the identification of $\mathrm{Ca}^{2+}$ permeable channels named TRP channels [9-11]. Ten years later in 1995, the first mammalian channel and founding member of the classical or canonical TRP family (TRPC1) was identified by homology screening in expressed sequence tag (EST) data bases (reviewed in [12]). Today, we know six TRP families with 28 different mammalian TRP channels. They are composed of intracellular N- and C-termini, six membrane-spanning helices (S1-S6), and a presumed pore forming loop (P) between S5 and S6 (reviewed in [13]). All TRPC family 
members harbor an invariant sequence, the TRP box (containing the amino acid sequence: EWKFAR), in its C-terminal tail as well as ankyrin repeats in the N-terminus [13]). For a functional TRPC ion channel complex, four monomers of the same type in a homotetrameric complex or four different TRPC monomers forming a heterotetrameric channel are essential [13]. All TRPC channels except TRPC1, whose role as ion channel or channel regulator is still a matter of debate [12], share a common activator diacylglycerol (DAG) [14,15] and are involved in complex cellular signal transduction cascades [16]. DAG is produced from phosphatidylinositol 4,5-bisphosphate $\left(\mathrm{PIP}_{2}\right)$ by phospholipase C-isozymes activated after agonist binding to appropriate receptors [16].

The sixth member of the TRPC family, TRPC6, is highly expressed in lung tissues and its function was extensively studied in precapillary pulmonary arterial smooth muscle (PASMC) as well as in lung endothelial cells (LEC). PASMC essentially regulate blood pressure in the lung like small mesenteric arteries in the systemic vasculature. Therefore, we set out to isolate PASMC by transferring a well-established isolation procedure from rat [17] to mouse models. Most interestingly, PASMC predominantly express TRPC6 next to TRPC1 but only minor amounts of TRPC3 channels [18] in contrast to large pulmonary arteries. Therefore, a compensatory up-regulation of TRPC3 like in arteries of the systemic vasculature of TRPC6-/- mice did not arise and a true TRPC6-deficiency phenotype was identified. The Euler-Liljestrand reflex or acute hypoxic vasoconstriction of the pulmonary vasculature, which redirects blood flow from the hypoxic areas of the lung to normoxic regions was absent in these mice [18]. The reflex assures sufficient oxygen supply, if parts of the lungs are blocked by inhaled particles or by invading microorganisms, and if not functional induces lethal arterial hypoxemia in TRPC6-deficient mice [18]. In pulmonary endothelial cells, $\mathrm{Ca}^{2+}$ influx through TRPC6 increases cellular permeability induced by hypoxia. Pharmacological tools revealed a signal transduction cascade from hypoxia-induced Nox2-activation, production of reactive oxygen species (ROS), which induce PLC $\gamma$-phosphorylation and DAG-kinase-inhibition leading to DAG accumulation and TRPC6 channel-induced $\mathrm{Ca}^{2+}$-influx in endothelial cells of the lung [19]. Therefore, TRPC6 channels are indirectly activated by hypoxia and channel-induced $\mathrm{Ca}^{2+}$-influx is responsible for smooth muscle cell contraction and increases in endothelial permeability.

While TRPC6 is only marginally expressed in fibroblasts, the channel is upregulated in myofibroblasts [20]. Initial results in cardiac and skin myofibroblasts [20] were reproduced in pulmonary myofibroblasts by my research group [21]. Next to these cells, TRPC6 is also expressed in alveolar macrophages [22], which are responsible for removing particles and microorganisms from the alveoli as well as in neutrophils [23,24], which migrate in lung tissues to fight against invading bacteria and viruses. Migration of TRPC6-/- neutrophils in response to macrophage inflammatory protein-2 (MIP2 also known as CXCL2) and CXR2-mediated chemotaxis was reduced in comparison to WT cells, while N-formyl-methionine-leucine-phenylalanine (fMLP) receptor-mediated chemotaxis was unchanged $[23,24]$. In summary, TRPC6 channels are highly expressed in lung tissues and are an interesting target for the development of therapeutic options in lung disease. Specific regulators of TRPC6 channels [25] are summarized in Table 1. Flufenamic acid is a rather unspecific TRPC/M/V channel blocker, but selectively activates TRPC6 and TRPA1 [25] and may be useful for the identification of channel activities in freshly isolated lung cells. Aniline-thiazoles [26] as well as small molecules from Glaxo-Smith-Kline (GSK2332255B and GSK2833503A) [27] block both closely related TRPC3 and TRPC6 channels. The latter compounds were already effective in reducing cardiac hypertrophy [27]. Another compound from Sanofi called SAR7334 effectively inhibited TRPC6 as well as TRPC3 and TRPC7 but not TRPC4 and TRPC5 [28]. More selective blockers are larixyl-derivates [29] especially larixyl N-methyl-carbamate with a nanomolar affinity to TRPC6 and a 13-fold subtype selectivity over TRPC3 [30]. Recently a small molecule inhibitor BTDM effective against TRPC3 and TRPC6 was identified, which binds to the S5-S6 pore domain of the human TRPC6 homotetramer analysed by single-molecule cryo-electron microscopy [31]. 
Table 1. Compounds regulating TRPC6 activity and prospective therapeutic options.

\begin{tabular}{ccccccc}
\hline Drug & TRPC6 & TRPC3 & TRPA1 & TRPV1 & Therapeutic Opt. & Ref. \\
\hline Flufenamic ac. & + & - & + & - & $?$ & {$[25]$} \\
Aniline-thiazole & - & - & $?$ & $?$ & $?$ & {$[26]$} \\
GSK comp. & - & - & $?$ & $?$ & Heart hypertrophy & {$[27]$} \\
Larixyl deriv. & - & $/$ & $/$ & $/$ & Lung edema & {$[29,30]$} \\
SAR7334 & - & - & $?$ & $?$ & $?$ & {$[28]$} \\
BTDM & - & - & $?$ & $?$ & $?$ & {$[31]$} \\
\hline
\end{tabular}

+, activating; -, inhibiting; ?, not tested; /, very low activity, ac., acid, GSK comp., GSK compounds GSK2332255B and GSK2833503A; Ref. reference.

In contrast to TRPC6, expression of TRPA1, the only member of the TRPA family of TRP channels with a characteristic high number (16 in humans) of N-terminal ankyrin, repeats in lung is still elusive. Ankyrin repeats that are responsible for the letter A in the channel's name are 33-amino-acid-motifs, which are found in many proteins and mediate protein-protein interaction. Several cysteine residues in these repeats were identified as targets for covalent modification by isothiocyanates, cinnamaldehyde, and acrolein known to be potent activators of TRPA1 [32]. Other activators of TRPA1 are histamine, prostaglandins, NGF, and bradykinin as important mediators of inflammation and pain after toxic injury [33]. Therefore, TRPA1 may mediate airway inflammation [34]. The channel was originally cloned in cultured fibroblasts [35] but also identified in cell lines of human lung fibroblasts (CCD19-Lu) and pulmonary epithelial cells (A549) [36]. The main in vivo expression, however, was found in neuronal tissues like spinal dorsal root ganglia (DRG), trigeminal ganglia [37], and bronchopulmonary afferent neurons, where the channel is co-expressed with TRPV1 [38] and is involved in detecting cold and hot temperatures as well as acrolein in cigarette smoke $[39,40]$. Moreover, TRPA1 protein was identified by immunohistochemistry in a subset of nodose ganglion neurons projecting to the lung and airway in mice [41]. Robust increases in intracellular $\mathrm{Ca}^{2+}$ were induced by hypoxia (10, $\left.13,15 \% \mathrm{O}_{2}\right)$ and hyperoxia $\left(100 \% \mathrm{O}_{2}\right)$ in a subset of these neurons, which were also sensitive to capsaicin a specific activator of TRPV1 channels [42]. Thus, nodose neurons from TRPA1-deficient mice were largely unresponsive to hypoxia and hyperoxia [42] and TRPA1 was activated by both hypoxia and hyperoxia in vitro. While hypoxia induces dihydroxylation of the proline residue 349 in an aminoterminal Ankyrin repeat, hyperoxia increases crosslinking of two carboxy-terminal cysteines (Cys633 and Cys856) [42]. Moreover, ozone $\left(\mathrm{O}_{3}\right)$, hypochlorite, and $\mathrm{H}_{2} \mathrm{O}_{2}$ as oxidizing agents activate TRPA1 as airborne irritants (reviewed in [33]). TRPA1 expression was also detected in non-neuronal tissues like lung epithelium by RT-PCR and immunohistochemistry [43] (see Table 5). However, as evidence for in vivo function of TRPA1 in non-neuronal lung tissues was still missing, we compared hyperoxia-induced increases in intracellular $\mathrm{Ca}^{2+}$ in TRPA1-/- and WT cells from tracheae, bronchi, and alveoli. While in all cells hyperoxia induced a rapid increase in intracellular $\mathrm{Ca}^{2+}$, no significant differences were detected in TRPA1-deficient cells compared to WT cells [44]. Along these lines, mice kept in a hyperoxic environment developed alveolar hyperplasia irrespective of their TRPA1 expression [44]. Although non-neuronal activation of TRPA1 was reported in airway inflammation [41], other TRPA1 functions in non-neuronal tissues remain elusive. TRPA1 is activated by a plethora of natural and artificial compounds [25], which cannot all be listed in a clear, structured table. Most interestingly, a lot of licensed drugs like acetaminophen [45], apomorphine [46], cannabinoids [45], chlorpromazine [47], oxaliplatin [48], chloroquine [49], etodolac [50], desflurane [51], and auranofin [52] activate TRPA1 and may be easily "repurposed/repositioned", if TRPA1 activation is part of a therapeutic option. TRPA1 inhibitors are listed in Table 2. While compounds like HC-030031 [53], Chembridge (CB)-5861528 [54], and AP18 [55] are effective in a $\mu$ molar range, A967079 reaches $\mathrm{IC}_{50} \mathrm{~s}$ of 67 and $289 \mathrm{nM}$ on human and rat TRPA1, respectively [56]. AZ465 blocks only human, but not mouse TRPA1 [57] and GRC17536 [58] is the most promising compound to date, which is in a phase II clinical trial as a therapeutic option for chronic refractory cough (reviewed in $[4,59])$. 
Table 2. Compounds inhibiting TRPA1 activity and prospective therapeutic options.

\begin{tabular}{cccccc}
\hline Drug & TRPA1 & TRPV1 & TRPV4 & Therapeutic Opt. & Ref. \\
\hline HC-030031 & - & $?$ & $?$ & Asthma & {$[40,53]$} \\
CB-5861528 & - & $?$ & $?$ & $?$ & {$[54]$} \\
AP18 & - & $/$ & $/$ & Toxic lung inj. & {$[55,60]$} \\
A967079 & - & $/$ & $/$ & $?$ & {$[56]$} \\
AZ465 & -1 & $?$ & $?$ & Cough & {$[57]$} \\
GRC17536 & - & $?$ & $?$ & $?$ & {$[58]$} \\
\hline
\end{tabular}

${ }^{1}$ human TRPA1; -, inhibiting; ?, not tested; /, very low activity; opt. options; Ref., reference.

TRPV1, as the first cloned member of the vanilloid family of TRP channels, was identified in sensory neurons, which were activated by capsaicin the pungent ingredient in hot chilli peppers [61]. Capsaicin binding sites are located in the transmembrane region S3 and the loop region between S2 and S3 [62]. TRPV1 is expressed in 50\% of small to medium size somatic and visceral neurons in dorsal root trigeminal and vagal ganglia [61,62]. Its expression is dependent on the production of nerve growth factor (NGF) or brain-derived neurotrophic factor (BDNF) as trophic signals $[63,64]$. Levels of both NGF and artemin, a member of the GDNF family, are increased during inflammation and up-regulated TRPV1 expression will contribute to thermal hypersensitivity [65]. Thus, TRPV1 contributes to heat $\left(>42{ }^{\circ} \mathrm{C}\right)[66]$ and pain sensation [67]. A complete lack of the acute withdrawal response to noxious heat, however, was only observed in triple TRPV1-/-TRPM3-/-TRPA1-/- deficient mice [68]. Along these lines, heterotetrameric functional channels composed of TRPV1 and TRPA1 were identified and characterized [69].

Next to its prominent expression in neuronal cells, TRPV1 was also identified in arterial smooth muscle cells, where it may control blood flow [70,71], human bronchial fibroblasts [72], and lung epithelial cells [73,74] (see Table 5). In the latter tissue, recent evidence indicate that TRPV1 channels are good candidates for the detection of inhaled toxicants and their antagonists may protect from toxic lung injury and pain related to chronic inflammation (reviewed in [3]). Proposed roles of TRPV1 in inflammation of the lung during the development of asthma and chronic obstructive lung disease (COPD) are discussed below. Therefore, TRPV1 is the number one TRP-target for developing new drugs by numerous companies (reviewed in $[25,75]$ ). Historically, capsicum plasters containing capsaicin from chilli peppers were sold for more than 100 years against back pain without revealing the molecular basis of their action. Now, we know that TRPV1 channels are the target of capsaicin and are rapidly desensitized by complex cellular signaling events [76]. Along these lines, capsaicin patches are already provided for patients with postherpetic neuralgia (reviewed in [25]) and intranasal application of capsaicin provided beneficial effects to patients with vasomotor rhinitis, but was not well tolerated [77]. Thus, numerous TRPV1 inhibitors [25] were also developed and some selective compounds are listed in Table 3. Resolvin D2 also equally effects TRPA1 channels [78], while BCTC [79] and agatoxin AG489 [80] were not further tested for their selectivity. More selective is ASBT102, which is not effectively inhibiting TRPV4 and TRPA1 [81]. Pretreatment with SB-7054978 was effective in reducing capsaicin-induced secondary hyperalgesia [82], but a randomized, double blind, placebo-controlled cross-over trial on cough sensitivity to capsaicin was not successful [83]. The compound JNJ-17203212 was inhibiting osteoarthritis pain in rat [84] and bone cancer pain in a mouse model [85]. Very promising compounds like AMG517 from Amgen [86] and AZD1386 [87], which were in clinical trials for reducing pain after tooth extraction, increase body temperature. Therefore, the therapeutic value of TRPV1 antagonists are still under debate. For up-to-date information, please refer to Lee et al. [88]. Two phase II trials (NCT02233686 and NCT02233699) with the drug xention-D0501 ended in 2015, but no results were posted. Very recently, JNJ-39439335 (Mavatrep) was analyzed in a phase I study in healthy Japanese and Caucasian men as prospective pain reliever [89,90]. In contrast to other TRPV1 antagonists, the most common side effects thermohypoesthesia as well as feeling cold or hot were well tolerated by the volunteers [89]. 
Table 3. Selected compounds inhibiting TRPV1 activity and prospective therapeutic options.

\begin{tabular}{cccccc}
\hline Drug & TRPV1 & TRPV4 & TRPA1 & Therapeutic Opt. & Ref. \\
\hline Resolvin D2 & - & $?$ & - & - & {$[78]$} \\
BCTC & - & $?$ & $?$ & - & {$[79]$} \\
Agatoxin AG489 & - & $?$ & $?$ & - & {$[80]$} \\
ABT102 & - & $/$ & $/$ & Tooth pain & {$[81]$} \\
AMG517 & - & $?$ & $?$ & Hyperalgesia & {$[82]$} \\
SB-7054978 & - & $?$ & $?$ & Asthma & {$[91]$} \\
“ & - & $?$ & $?$ & Tooth pain & {$[87]$} \\
AZD-1386 & - & $?$ & $?$ & Osteoarthritis pain & {$[84]$} \\
JNJ-17203212 & - & & & Bone cancer pain & {$[77]$} \\
“ & & & & COPD & {$[92]$} \\
JNJ-39439335 & - & $?$ & $?$ & various pain cond. & {$[89]$} \\
\hline
\end{tabular}

-, inhibiting; ?, not tested; /, very low activity; opt. options; Ref., reference.

The fourth member of the TRPV family, TRPV4, was identified in 2000 [93-95] and originally described as an osmo-sensitive channel [94], but is also sensitive to heat $\left(<24{ }^{\circ} \mathrm{C}\right)$ [96], shear stress [97], and various chemical stimuli (see below). In human patients several mutations and single nucleotide polymorphisms (SNPs) in the TRPV4 gene are closely linked to different skeletal dysplasias, neuropathies, hyponatremia, as well as chronic obstructive pulmonary disease (COPD) (reviewed in [98] and see below). Like TRPV1, TRPV4 is expressed in the central nervous system and the brain, not only in neurons, but also in glial cells and astrocytes [98]. The channel senses intravesicular pressure in the bladder and is involved in regulation detrusor function (reviewed in [99]) and was identified in keratinocytes [100]. TRPV4 is also expressed in endothelial cells (reviewed in [101]), where it activates $\operatorname{IK}(\mathrm{Ca})$ channels for vasodilatation and blood flow autoregulation [102]. Next to bronchial epithelial cells [103], the channel is also functional in airway smooth muscle cells [104] and contributes to the ciliary beat frequency regulation in tracheal epithelial cells [105]. Serotonin-induced pulmonary vasoconstriction and the enhanced vascular reactivity in chronic hypoxic pulmonary vasoconstriction is dependent on TRPV4 [106]. TRPV4 activation reduces the alveolar barrier [107] and activates macrophages [108] contributing to acute lung injury.

Along these lines, several reports confirm a role of TRPV4 in the disruption of the epithelial barrier and the formation of lung edema (reviewed in [109]). In other tissues however, the channel also contributes to the formation of the cellular barrier e.g. in skin [110], the urogenital tract [111] and the corneal epithelium [112]. Therefore, the application of TRPV4 antagonists may induce multiple harmful side effects. A selection of compounds [25] activating or inhibiting TRPV4 are listed in Table 4. The $4 \alpha$ phorbol esters [113] and epoxyeicosatrienoic acids (EET) [114] work as endogenous mediators of TRPV4. Bisandrographolide A [115] is a selective TRPV4 activators which does only weakly modulate other members of the vanilloid family like TRPV1, TRPV2, and TRPV3. GSK1016790A, the only in vivo tested so-called "superagonist", causes a lethal drop in blood pressure in mice, cats, and dogs [116], while intravesical instillation caused bladder overactivity in mice [117]. Both effects, however, were only observed in wild-type, but not in TRPV4-deficient mice [116,117], emphasizing the important roles of the channel in endothelium-dependent vasorelaxation and bladder function. RN-1734 [118] and GSK205 [119] are moderate TRPV4 inhibitors blocking in the $\mu \mathrm{M}$ range, which were tested only in vitro. In vivo application of HC-067047 improved bladder function in mice and rats with cystitis induced by the application of the cytostatic compound cyclophosphamide [120]. GSK2193874 was effective in preventing pulmonary edema due to acute and chronic heart failure in mice [121]. This inhibitory effect on edema formation was reproduced in a human disease model-on-a-chip [122]. The probably most promising compound GSK2798745 was analyzed in phase I and phase II studies in patients with congestive heart failure and initial results are posted (NCT02119260 and NCT02497937 see https://clinicaltrials.gov/). 
Table 4. Selected compounds activating or inhibiting TRPV4.

\begin{tabular}{ccccccc}
\hline Drug & TRPV4 & TRPV1 & TRPV2/3 & TRPM8 & $\begin{array}{c}\text { Therapeutic } \\
\text { Opt. }\end{array}$ & Ref. \\
\hline 4 $\alpha$-phorbolesters & + & $/$ & $/$ & $?$ & - & {$[113]$} \\
EETs & + & $?$ & $?$ & $?$ & - & {$[114]$} \\
Bisandrograph. & + & $/$ & $/$ & $?$ & - & {$[115]$} \\
GSK1016790A & + & $/$ & $?$ & $?$ & Blood pressure $\downarrow$ & {$[109]$} \\
RN1734 & - & $/$ & $/$ & $/$ & - & {$[118]$} \\
GSK205 & - & $?$ & $?$ & $?$ & - & {$[119]$} \\
HC-067047 & - & $/$ & $/$ & $/$ & Cystitis & {$[120]$} \\
“ & & & & & COPD & {$[92]$} \\
GSK2193874 & - & $?$ & $?$ & $?$ & Pulm. edema & {$[121]$} \\
\hline
\end{tabular}

+ , activating; -, inhibiting; ?, not tested; /, very low activity; $\downarrow$, reduction, opt., options, Ref., reference.

\section{Non-Neuronal TRPs as Potential Drug Targets in Lung Disease}

TRP channels are expressed in many cells of the lung (see Figure 1) as outlined above and summarized in Table 5. In the upper airways and bronchi ciliated epithelial cells together with mucus producing goblet cells remove foreign particles. Airway smooth muscle cells (SMC) are able to constrict or relax the airways to meet the demand of oxygen in the body. The smaller bronchioles end in thousands of small air sacs called alveoli composed of alveolar type 1 (AT1) and alveolar type 2 (AT2) cells. The latter produce surfactant protein-C (SP-C) to facilitate gas exchange $\left(\mathrm{O}_{2}\right.$, oxygen; $\mathrm{CO}_{2}$, carbon dioxide) through the alveolar capillary membrane with erythrocytes in the accompanying blood vessels. Alveolar macrophages (MP) clean the alveolus by phagocytosis. While the alveolar capillary membrane consists only of the alveolar epithelium, an interstitium (not depicted) and endothelial cells, precapillary, small and large pulmonary arteries are contractile by smooth muscle cells (e.g., precapillary arterial smooth muscle cells (PASMC). TRP channels do not seem to be essential for normal function of the lungs and airways, as TRP-deficient mice do not show any obvious pulmonary defects. Only for TRPV4-/- mice was an altered beat frequency of tracheal epithelial cells observed [105]. However, these proteins, as so-called "alarm channels", are important for the compensation of pathophysiological conditions and may induce chronic diseases, like pain and decreased cell barrier function induced by over-active inflammation processes, if their activity is not strictly regulated. In these disease states, selective modulators of TRP channels are attractive new therapeutic options, which may induce only minor side effects, because normal cell function is not compromised. I will briefly introduce these pathological alterations in lung functions and summarize the involvement of pulmonary TRP channels in the progress of the disease in the following sections of this chapter.

Table 5. TRP expression patterns in lung cells.

\begin{tabular}{ccccc}
\hline Lung Cell & TRPA1 & TRPC6 & TRPV1 & TRPV4 \\
\hline Bronchial epi. & $-/+[44]^{1}{ }^{1}[43]^{3}$ & $+[123]^{2}$ & $+[124]^{3}$ & $+[92]^{2}$ \\
Airway SMC & $-/+[44]^{1}$ & $+[123]^{2}$ & $+[70]^{3}$ & $+[104]^{2}$ \\
AT1 cells & $-/+[44]^{1}$ & $?$ & $?$ & $?$ \\
AT2 cells & $-/+[44]^{4}$ & $?$ & $?$ & $?$ \\
Alveolar MP & $?$ & $+[22]^{4}$ & $?$ & $+[125]^{5}$ \\
Endothelium & $-/+[44]^{1}$ & $+[19]^{4}$ & $+[126]^{2}$ & $+[126]^{2}$ \\
PASMC & $-/+[44]^{1}$ & $+[18]^{2}$ & $+[127]^{4}$ & $+[127]^{2}$ \\
Neutrophils & $?$ & $+[23]^{3}$ & $?$ & $+[23]^{2}$ \\
Fibroblasts & $-/+[44]^{1}$ & $-/+[21]^{2}$ & $?$ & $+[128]^{4}$ \\
Myofibroblasts & $?$ & $+[21]^{4}$ & $?$ & $+[128]^{4}$ \\
\hline
\end{tabular}

$-/+$, very low expression, + , expression,,++ high expression, ?, not tested. References in brackets []. Detection by: ${ }^{1}$ labeling of specific mRNA (nanostring $®$ technology); ${ }^{2}$ amplification of specific mRNA by quantitative reverse transcription (qRT)-PCR; ${ }^{3}$ imunohistochemistry, ${ }^{4}$ labeling protein by specific antibodies in a Western Blot, ${ }^{5}$ functional assays. 


\subsection{Cystic Fibrosis (CF)}

$\mathrm{CF}$ patients carry mutations in the gene for the cystic fibrosis transmembrane conductance regulator (CFTR), an ion channel managing the passage of chloride and bicarbonate ions across the apical membrane of epithelial cells. Identified mutations in CF result in improper translation, processing and translocation of the CFTR protein to the plasma membrane as well as impaired conductance and regulation of the ion channel (reviewed in [129]). All mutated proteins, including the most common F508del CFTR mutation, induce production of high quantities of abnormal mucus of high viscosity (see Figure 2a), which is not suitable for the removal of particles as well as bacteria and viruses from the airways [129]. CF patients are suffering from compromised respiratory function, chronic infection in particular by Pseudomonas aeruginosa, and inflammation seriously damaging lung tissues [130].
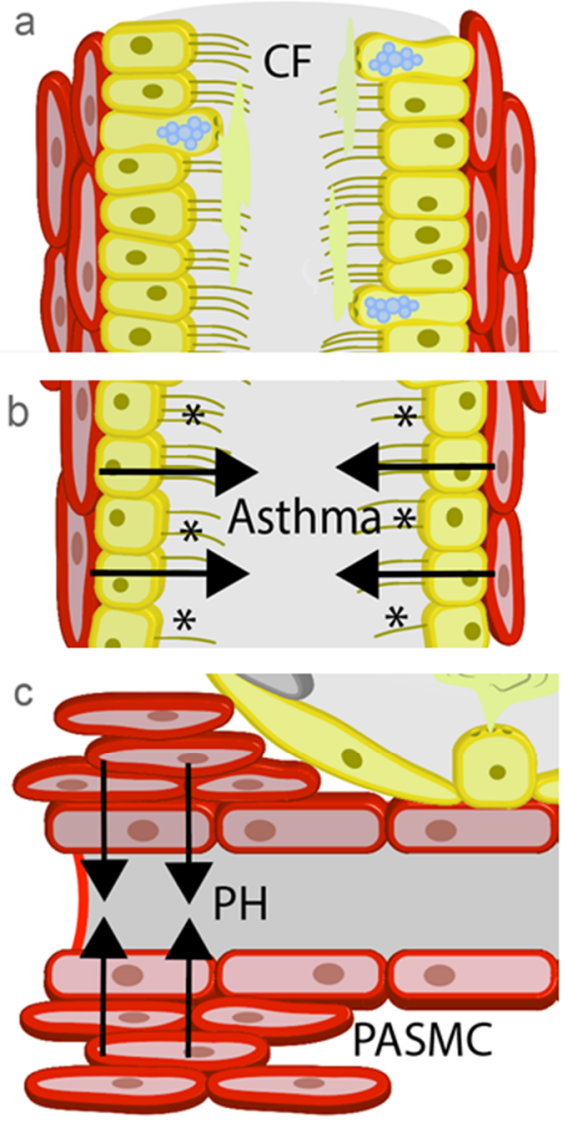

d
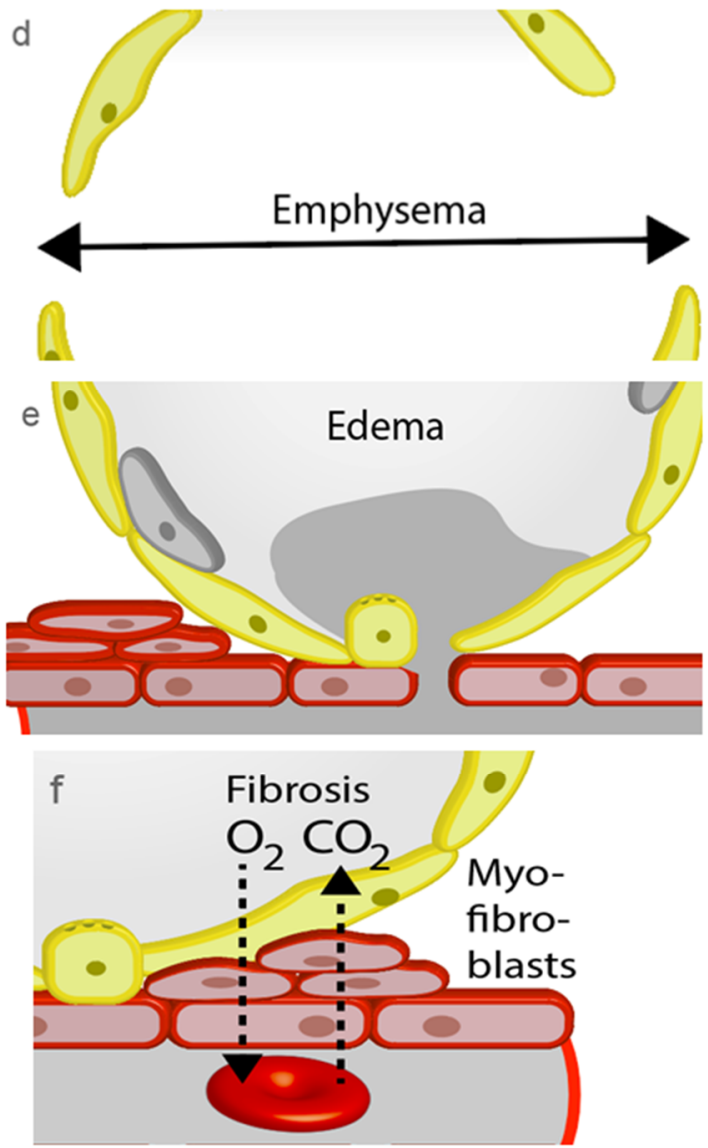

Figure 2. Pathophysiological changes in the lung. (a) Increasing viscosity of the mucus during the development of cystic fibrosis (CF) disables removal of foreign particles. (b) Contractions of the airways by allergens ${ }^{*}$ ) occur during an asthma attack and prevents gas exchange. (c) Precapillary arterial smooth muscle cell (PASMC) contract to increase pulmonary blood pressure as an initial step in the development of pulmonary hypertension (PH). (d) A hallmark of chronic obstructive pulmonary disease (COPD) is the loss of alveolar septae during the development of emphysema. (e) Increased hydrostatic pressure by $\mathrm{PH}$ or damage of the alveolar capillary membrane induce lung edema. (f) Repair processes by myofibroblasts block gas exchange in the alveolar capillary membrane of patients with lung fibrosis.

The TRPA1 protein was identified in bronchial epithelial cells and inhibition of its expression results in reduction of the release of several cytokines from these cells (IL-8, IL-1 $\beta$, TNF $\alpha$ ) in response to exposure to P. aeruginosa [131]. These data point to an important function of TRPA1 in airway inflammation during $\mathrm{CF}$ pathogenesis. 
Most interestingly, CFTR down-regulates TRPC6-mediated $\mathrm{Ca}^{2+}$ influx, while TRPC6 up-regulates CFTR-mediated $\mathrm{Cl}^{-}$transport, and both proteins physically interact with each other [132]. Therefore, TRPC6-mediated $\mathrm{Ca}^{2+}$ influx was increased in CF versus non-CF human epithelial cells, because functional coupling of CFTR and TRPC6 is lost. This mechanism called reciprocal coupling has also been observed in freshly isolated ciliated epithelial cells [132], which regulate mucus viscosity by CFTR activity. While the correction of transportation and function of the CFTR protein in epithelial cells was the main aim in the treatment of CF in the last years, a new paradigm also points to other possible targets. Dysregulated innate immunity [133] especially in neutrophils [134] and macrophages [135] is also responsible for defects in bacterial clearance observed in CF patients. Both cell types express TRPC6 proteins (see Table 5) as well as CFTR ion channels. Phagocytic capacity as well as fusion of phagosomes with lysosomes are not affected by mutated CFTR proteins, but bacteria are not destroyed and are even able to multiply in CF macrophages [136,137]. Moreover, CF neutrophils are unable to kill invading bacteria [138]. Most interestingly, a drug called roscovitine, which is tested in clinical studies as therapeutic option for a plethora of diseases, acts as a partial corrector of the F508del CFTR protein [139] and recruits TRPC6 translocation to phagosomal membranes, which is able to restore microbicidal function in alveolar macrophages compromised by CF [140]. Other functions of this drug on neutrophils, epithelial cells, eosinophils, and lymphocytes may also be beneficial to restore activity in CF affected cells (reviewed in [141]).

TRPV4 is important for the regulatory volume decrease (RVD) in airway epithelia, which is absent in CF airways, but could be recovered by $4 \alpha$-phorbolesters as TRPV 4 activators [142] (see Table 4 ). Specific inhibitors of these TRP channels need to be evaluated in clinical studies in the future.

\subsection{Asthma}

Asthma is a chronic inflammatory disease of the upper airways induced by repeated exposure to specific allergens, which results in activation of epithelial cells and acute bronchoconstriction (see Figure 2b). Differentiated T-helper 2 (Th2), mast cells, and eosinophils invade lung tissues and up-regulation of mediators of inflammation like IL-4, IL-5, IL-13 eotaxin (CCL11) and eicosanoids is observed. Patient suffer from symptoms like cough, dyspnea, wheezing, and chest tightness [143]. A longer-lasting response is also triggered by isocyanate [144], exercise, and cold air, releasing tachykinins and calcitonin gene-related peptide to promote neurogenic inflammation. Asthma patients inhale rapid and long-acting $\beta_{2}$-adrenoceptor agonists for bronchodilation and glucocorticoids to inhibit chronic inflammation [145]. These current treatment options offer only symptomatic relief to the majority, but not all patients [146]. There are, however, no therapeutic options to date that are able to prevent or cure asthma [145].

Airway inflammation and hyper-reactivity can be mimicked in an established ovalbumineinduced mouse model. TRPA1-deficient $\left(\right.$ TRPA1 $^{-/-}$) mice or wild-type (WT) mice treated with the TRPA1 inhibitor HC-030031 (see Table 2) showed significant lower allergen-induced leucocyte infiltration, cytokine, and mucus production as well as airway hyper-reactivity [40]. The same was true in a mouse model of hypochlorite $\left(\mathrm{ClO}^{-}\right)$exposure followed by ovalbumin treatment. Here, airway hyper-responsiveness was induced without bronchial inflammation and was again significant reduced in TRPA1 ${ }^{-/-}$mice [147]. In both cases, however, global TRPA1-deficient mice were used and neuronal expressed TRPA1 channels were most probably responsible for disease symptoms. The role of TRPA1 in epithelial cells activated by e.g., isocyanates remains therefore elusive.

In TRPC6-deficient mice, ovalbumine sensitization resulted in reduced allergic responses as evidenced by a decrease in airway eosinophilia and blood IgE levels, as well as decreased levels of Th2 cytokines (IL-5, IL-13) in the bronchoalveolar lavage [123]. Surprisingly, TRPC6 ${ }^{-/-}$mice exposed increased methacholin-induced bronchoconstriction due to compensatory up-regulation of related but constitutively active TRPC 3 channels $[123,148]$. Along these lines, two recent reports were able to inhibit allergen-induced asthma by lentiviral knock-down or inhibition of TRPC3 [149,150]. 
TRPV1 is significantly higher expressed in bronchial epithelia of asthma patients than in healthy volunteers [124] and a loss of function single nucleotide polymorphism (SNP) changing the amino acid isoleucine to valine (I585V) lowers the risk of active childhood asthma [151]. Contradictory data were produced with TRPV1 modulators. The use of two TRPV1 inhibitors (SB-705498 see Table 3 and PF-04065463) inhibited ovalbumin-induced airway hyper-responsiveness to histamine in guinea pig [91], while another blocker (SB366791) failed to reduce eosinophil infiltration in a mouse model of allergic asthma [152]. It is again, however, not clear, in which tissue (neuronal or non-neuronal) TRPV1 is mediating allergic responses to asthma.

In a house dust mite model, which is more relevant to the human situation, TRPV4-/- mice were protected from airway remodeling and fibroblasts isolated from asthmatic human patients exposed increased TRPV4 activity compared to cells from healthy donors. Therefore, TRPA1, TRPV1, and TRPV4 are most promising pharmacological targets for new asthma therapeutics and already effective modulators are ready for use in clinical trials.

\subsection{Pulmonary Hypertension (PH)}

$\mathrm{PH}$ by remodeling of the pulmonary vessels leads to a progressive increase in pulmonary vascular resistance, due to proliferation and constriction of smooth muscle cells in the precapillary small arteries (see Figure 2c), which are responsible for blood pressure regulation in the lung. PH can be induced by left heart failure, chronic lung disease, hypoxia, thromboembolic events, or other unknown multifactorial mechanisms (reviewed in [153]). Hitherto known therapeutic options include endothelin receptor antagonists, phosphodiesterase 5 inhibitors, guanylyl cyclase stimulators, prostaglandin receptor agonist, and prostaglandin analogues [154].

TRPC6 is essential for the acute phase of hypoxia-induced pulmonary vasoconstriction (HPV), which is absent in TRPC6-/- mice [18] and can be reduced by a TRPC6 selective larixylmethyl-derivate (see Table 1 and [29]). Data for remodeling processes induced by chronic hypoxia $\left(10 \% \mathrm{O}_{2}\right.$ for $\geq 3$ weeks), however, are contradictory. We have demonstrated that TRPC6-deficient mice display chronic hypoxia-induced $\mathrm{PH}$ indistinguishable from those in wild-type (WT) mice [18]. In TRPC1/6-double-deficient mice, PH was decreased after exposure to chronic hypoxia and muscularization of lung microvessels was inhibited compared to WT mice [155], indicating that both TRPC channels may be responsible for the development of PH. In two other reports, notch-induced up-regulation of TRPC6 [156] and CFTR-mediated translocation of TRPC6 to caveolae [157] were responsible for chronic $\mathrm{PH}$. While strain and sex differences may be responsible for the different results, all these observations in mouse models clearly demand more studies in human patients. In fact, mRNA and protein expression of TRPC6 in lung tissues and PASMCs from patients with idiopathic pulmonary arterial hypertension (IPAH), which develop the disease due to unknown reasons, is much higher than in those from normotensive patients [158]. Furthermore, inhibition of TRPC6 gene expression by small interfering RNA (siRNA) significantly diminished proliferation of PASMCs from IPAH patients [158]. Moreover, TRPC6 regulatory regions of 268 patients with IPAH revealed three SNPs. One of them $(-254(C>G))$ increased basal TRPC6 gene promoter activity and introduces a new binding site for the inflammatory transcription factor $\kappa B(N F \kappa B)$ [159] probably mediating inflammatory mechanisms, which are also observed during the development of PH [160].

Similar results like for TRPC6 were demonstrated for TRPV4, which is also responsible for acute and chronic hypoxic vasoconstriction $[161,162]$ and might form functional heteromeric channels with TRPC6, as both co-immunoprecipitate in PASMC lysates [162].

Thus, specific TRPC6 and TRPV4 inhibitors (see Tables 1 and 4) might be successful in the therapy of $\mathrm{PH}$ in the future.

\subsection{Chronic Obstructive Pulmonary Disease (COPD)}

Chronic bronchitis, bronchiolitis, and emphysema are summarized by the term COPD. While the first two pathologies result in cough, fever, and dyspnea, the development of emphysema is 
characterized by an enlargement of alveoli (see Figure 2d), causing shortness of breath $[3,163]$. The vast majority of COPD patients are smokers [164], but exposure to wood smoke is also an important initiator of the disease [165]. Activation of lung resident immune cells, accumulation of inflammatory cells, e.g., neutrophils, and secretion of IL-1 $\beta$ and IL- 8 are typical symptoms of COPD. In addition to drugs used for the treatment of asthma, parasympatholytics like ipratropium bromide serve as therapeutics, but are no causal intervention and are far from curing the disease [3].

As outlined above, acrolein from cigarette smoke activates TRPA1 and an acrolein-induced increase in IL-8 secretion is significantly blocked by the TRPA1 antagonists AP18 (see Table 2) [60].

Airway inflammation in COPD patients is closely related to the invasion of neutrophils, because neutrophil counts were increased in the sputum of COPD patients and correlate to their disease state [166]. TRPC6 is expressed in neutrophils, is important for their migration [23,24] and may contribute to the progress of the disease. Moreover, TRPC6 mRNA was significantly up-regulated in lung macrophages of smokers, while TRPC 3 and TRPC7 mRNA expression was similar in comparison to non-smokers [22].

Along the same line, the TRPV1 activator capsaicin raised IL-8 secretion dose dependently from airway epithelial cells [124] and induced increased cough response in COPD patients compared to healthy volunteers by activating neuronal TRPV1 [167]. Strikingly, TRPV1 and TRPV4 mRNA levels were increased in samples from patients with COPD and cigarette-exposure-induced ATP release from primary bronchial epithelial cells was attenuated by blockers of both channels (JNJ1703212, HC087047 see Tables 3 and 4, [92]). Furthermore, increased levels of TRPV4 transcripts by gene polymorphisms are associated with COPD [168] and TRPV4 is highly expressed in alveolar macrophages (see Table 5). In summary, data for an involvement of TRP channels in the development of COPD are promising and should justify further studies in patients.

\subsection{Lung Edema}

Flooding of the alveoli due to lung edema (see Figure 2e) hampers gas exchange and may induce life threatening arterial hypoxemia. Endothelial dysfunction in the pulmonary vessels by toxic agents e.g., cytostatic drugs and smoke adducts circulating in the blood is one important reason for edema formation. Increased hydrostatic pressure by left heart failure leads to higher ventricular pressure transmitting back to the pulmonary circulation and may also increase endothelial permeability as well as trigger edema formation [3]. During pulmonary inflammation in patients with acute respiratory distress syndrome (ARDS) mediators like platelet-activating factor (PAF) [169] are also able to decrease endothelial barrier function in between minutes. In a fourth mechanism ischemia increases endothelial permeability initiating edema in isolated lungs intended for transplantation. Subsequently, invading immune cells are responsible for inflammation destroying urgently needed lung transplants [170].

TRPC6 and TRPV4 are expressed in endothelial cells (see Table 5) and there are numerous reports presenting evidence for their involvement in lung edema formation. We were able to demonstrate an essential role of TRPC6 in lung ischemia-reperfusion-induced edema (LIRE) formation and developed a novel mechanistic model [19] (see above). Most interestingly, a larixylderivate as selective TRPC6 blocker (see Table 1) was able to inhibit LIRE [30] a significant cause of primary graft failure in lung transplantation technology [170]. Translocation of TRPC6 to caveolae enriched with ceramide, an important product of the PAF signaling pathway, was found to be enhanced in pulmonary endothelial cells after application of PAF [171]. The resulting $\mathrm{Ca}^{2+}$ influx through TRPC6 can at least partly explain increases in endothelial permeability. Lipopolysaccharide (LPS) as an endotoxin produced by invading bacteria in septic patients is also able to activate TRPC 6 and increase endothelial permeability in a Toll-like receptor 4 (TLR4)-dependent manner [172]. LPS binding to TLR4 induces DAG production by a still unknown mechanism, which activates TRPC6 [172]. Therefore, TRPC6 inhibitors may also help to prevent acute lung injury in septic patients.

Along the same lines, TRPV4, a key regulator of lung endothelial barrier function (reviewed in $[101,109])$, is directly activated by LPS independently of and faster than the TLR4 pathway [173]. 
TRPV4-deficency reduces hydrostatic lung edema formation and capillary leakage [174,175], which can be explained by stretch induced activation of TRPV4 resulting in increased endothelial $\mathrm{Ca}^{2+}[176]$ and activation of endothelial NO production [177]. Most interestingly, the TRPV4 blocker GSK2193874 (see Table 4) was effective in inhibiting lung edema by high pulmonary venous pressure as well as in a myocardial infarction mouse model [121]. Vice versa, activation of TRPV4 by $4 \alpha$-phorbol esters (see Table 4) initiates lung edema [178]. Acid aspiration by gastroesophageal reflux results in acute lung injury with infiltration of macrophages and neutrophils. Protection from these symptoms was achieved in TRPV4-/- mice as well as in wild-type mice after application of TRPV4 blockers (GSK2220961, GSK2337429A) in a therapeutic approach $30 \mathrm{~min}$ after exposure, thus assembling the clinical situation [125]. GSK2193874 (see Table 4), however, needed to be applied before injury and showed only a prophylactic effect [175]. Proposed molecular mechanisms of edema formation by TRPV4 include $\mathrm{Ca}^{2+}$-induced activation of myosin light chain kinase (MLCK) in endothelial cell (reviewed in [101]) as well as opening of $\mathrm{Ca}^{2+}$-activated $\mathrm{K}^{+}$channels (KCa3.1) in epithelial cells inducing hyperpolarization [179]. The latter effect may provide the driving force for $\mathrm{Cl}^{-}$through $\mathrm{Ca}^{2+}$ activated $\mathrm{Cl}^{-}(\mathrm{CaCC})$ as well as CFTR channels causing extracellular liquid accumulation (reviewed in [180]). Therefore, TRPC6 and TRPV4 are attractive targets for developing new therapeutic options for patients with lung edema.

\subsection{Lung Fibrosis}

An impaired repair process after chronic lung damage by toxicants (e.g., the cytostatic drug bleomycin) is able to induce lung fibrosis, which is characterized by an accumulation of fibroblasts differentiating to myofibroblasts in response to secreted profibrotic transforming growth factor $\beta$ (TGF- $\beta 1$ ) [181]. Myofibroblasts express $\alpha$-smooth muscle actin as well as secret large amounts of extracellular matrix, e.g., collagens and accumulate in fibroproliferative foci, which inhibit gas exchange (Figure 2f). Despite recent progress with the approval of the drugs pirfenidone and nintedanib for the treatment pulmonary fibrosis, the only causative treatment is still lung transplantation.

Deficiencies of TRPC6 [21] and TRPV4 [128] independently protected lungs in a mouse model of bleomycin-induced lung fibrosis. While TRPC6 is not expressed in quiescent fibroblasts but is up-regulated by TGF- $\beta 1$ and is involved in myofibroblasts differentiation [21], TRPV4 is constitutively expressed in lung fibroblasts and may be engaged by mechanical stress [128]. Although many different cell types are involved in the development of lung fibrosis [181], both reports exclusively analyzed fibroblasts-myofibroblast-transdifferentiation and employed globally gene-deficient mice. Only tissue specific TRP-deficiency will answer the question which cells apart from fibroblasts are responsible for the development of lung fibrosis due to TRPC6 or TRPV4 function.

\section{Conclusions}

As outlined above, TRP channels do not contribute to normal lung function, but are involved in repair processes (e.g., increases in endothelial permeability, inflammation, myofibroblast differentiation) which might become pathologic. Therefore, they are ideally suited as pharmacological targets to develop new therapeutic options with less side effects. The most compounds already tested in clinical phases exist for TRPV1 as new drugs for pain relief, followed by modulators for TRPV4 efficient against lung edema. Only a few drugs exist for regulating TRPC6 activity and only one of them was successfully blocking lung edema in vitro. The same is true for TRPA1 with one drug being successful in the reduction of airway inflammation in a mouse model of asthma. In summary, translational research in patients and human tissues still have to validate initial data obtained in animal experiments and phase I and II clinical studies. In case of positive results, specific modulators of these channels may serve as new therapeutic options acting after resorption from the vasculature or from the airways after inhalation. 
Funding: Research in the author's laboratory was funded by grants from the Deutsche Forschungsgemeinschaft (DFG) (Transregional collaborative research center 152 (TRR152, project 16) on maintenance of body homeostasis by TRP channel modules and research training group 2338 (GRK2338, project 04) on targets in toxicology) and from the German Center for Lung research (DZL).

Acknowledgments: I would like to thank Thomas Gudermann as the head of the institute for his continuous generous support and all my lab members especially Katharina Hofmann and Martina Kannler for providing the latest data summarized in this review. Technical support by Bettina Braun and Astrid Bauer is greatly appreciated and I am grateful for the design of the figures by Matthias Dietrich.

Conflicts of Interest: The author declares no conflict of interest.

\section{References}

1. Canning, B.J.; Mori, N.; Mazzone, S.B. Vagal afferent nerves regulating the cough reflex. Respir. Physiol. Neurobiol. 2006, 152, 223-242. [CrossRef] [PubMed]

2. Desai, T.J.; Brownfield, D.G.; Krasnow, M.A. Alveolar progenitor and stem cells in lung development, renewal and cancer. Nature 2014, 507, 190-194. [CrossRef] [PubMed]

3. Dietrich, A.; Steinritz, D.; Gudermann, T. Transient receptor potential (TRP) channels as molecular targets in lung toxicology and associated diseases. Cell Calcium 2017, 67, 123-137. [CrossRef] [PubMed]

4. Belvisi, M.G.; Birrell, M.A. The emerging role of transient receptor potential channels in chronic lung disease. Eur. Respir. J. 2017, 50. [CrossRef] [PubMed]

5. Bonvini, S.J.; Belvisi, M.G. Cough and airway disease: The role of ion channels. Pulm. Pharmacol. Ther. 2017, 47, 21-28. [CrossRef] [PubMed]

6. Millqvist, E. TRPV1 and TRPM8 in Treatment of Chronic Cough. Pharmaceuticals 2016, 9, 45. [CrossRef] [PubMed]

7. Steinritz, D.; Stenger, B.; Dietrich, A.; Gudermann, T.; Popp, T. TRPs in Tox: Involvement of Transient Receptor Potential-Channels in Chemical-Induced Organ Toxicity-A Structured Review. Cells 2018, 7, 98. [CrossRef] [PubMed]

8. Minke, B.; Wu, C.; Pak, W.L. Induction of photoreceptor voltage noise in the dark in Drosophila mutant. Nature 1975, 258, 84-87. [CrossRef] [PubMed]

9. Montell, C.; Jones, K.; Hafen, E.; Rubin, G. Rescue of the Drosophila phototransduction mutation trp by germline transformation. Science 1985, 230, 1040-1043. [CrossRef] [PubMed]

10. Montell, C.; Rubin, G.M. Molecular characterization of the Drosophila trp locus: A putative integral membrane protein required for phototransduction. Neuron 1989, 2, 1313-1323. [CrossRef]

11. Hardie, R.C.; Minke, B. The trp gene is essential for a light-activated $\mathrm{Ca}^{2+}$ channel in Drosophila photoreceptors. Neuron 1992, 8, 643-651. [CrossRef]

12. Dietrich, A.; Fahlbusch, M.; Gudermann, T. Classical Transient Receptor Potential 1 (TRPC1): Channel or Channel Regulator? Cells 2014, 3, 939-962. [CrossRef] [PubMed]

13. Nilius, B.; Szallasi, A. Transient receptor potential channels as drug targets: From the science of basic research to the art of medicine. Pharmacol. Rev. 2014, 66, 676-814. [CrossRef] [PubMed]

14. Dietrich, A.; Mederos y Schnitzler, M.; Kalwa, H.; Storch, U.; Gudermann, T. Functional characterization and physiological relevance of the TRPC3/6/7 subfamily of cation channels. Naunyn Schmiedebergs Arch. Pharm. 2005, 371, 257-265. [CrossRef] [PubMed]

15. Storch, U.; Forst, A.L.; Pardatscher, F.; Erdogmus, S.; Philipp, M.; Gregoritza, M.; Mederos, Y.S.M.; Gudermann, T. Dynamic NHERF interaction with TRPC4/5 proteins is required for channel gating by diacylglycerol. Proc. Natl. Acad. Sci. USA 2017, 114, E37-E46. [CrossRef] [PubMed]

16. Dietrich, A.; Kalwa, H.; Rost, B.R.; Gudermann, T. The diacylgylcerol-sensitive TRPC3/6/7 subfamily of cation channels: Functional characterization and physiological relevance. Pflugers Arch. 2005, 451, 72-80. [CrossRef] [PubMed]

17. Waypa, G.B.; Chandel, N.S.; Schumacker, P.T. Model for hypoxic pulmonary vasoconstriction involving mitochondrial oxygen sensing. Circ. Res. 2001, 88, 1259-1266. [CrossRef] [PubMed]

18. Weissmann, N.; Dietrich, A.; Fuchs, B.; Kalwa, H.; Ay, M.; Dumitrascu, R.; Olschewski, A.; Storch, U.; Mederos y Schnitzler, M.; Ghofrani, H.A.; et al. Classical transient receptor potential channel 6 (TRPC6) is essential for hypoxic pulmonary vasoconstriction and alveolar gas exchange. Proc. Natl. Acad. Sci. USA 2006, 103, 19093-19098. [CrossRef] [PubMed] 
19. Weissmann, N.; Sydykov, A.; Kalwa, H.; Storch, U.; Fuchs, B.; Mederos y Schnitzler, M.; Brandes, R.P.; Grimminger, F.; Meissner, M.; Freichel, M.; et al. Activation of TRPC6 channels is essential for lung ischaemia-reperfusion induced oedema in mice. Nat. Commun. 2012, 3, 649. [CrossRef] [PubMed]

20. Davis, J.; Burr, A.R.; Davis, G.F.; Birnbaumer, L.; Molkentin, J.D. A TRPC6-dependent pathway for myofibroblast transdifferentiation and wound healing in vivo. Dev. Cell 2012, 23, 705-715. [CrossRef] [PubMed]

21. Hofmann, K.; Fiedler, S.; Vierkotten, S.; Weber, J.; Klee, S.; Jia, J.; Zwickenpflug, W.; Flockerzi, V.; Storch, U.; Yildirim, A.O.; et al. Classical transient receptor potential 6 (TRPC6) channels support myofibroblast differentiation and development of experimental pulmonary fibrosis. Biochim. Biophys. Acta 2017, 1863, 560-568. [CrossRef] [PubMed]

22. Finney-Hayward, T.K.; Popa, M.O.; Bahra, P.; Li, S.; Poll, C.T.; Gosling, M.; Nicholson, A.G.; Russell, R.E.; Kon, O.M.; Jarai, G.; et al. Expression of transient receptor potential C6 channels in human lung macrophages. Am. J. Respir. Cell Mol. Biol. 2010, 43, 296-304. [CrossRef] [PubMed]

23. Damann, N.; Owsianik, G.; Li, S.; Poll, C.; Nilius, B. The calcium-conducting ion channel transient receptor potential canonical 6 is involved in macrophage inflammatory protein-2-induced migration of mouse neutrophils. Acta Physiol. 2009, 195, 3-11. [CrossRef] [PubMed]

24. Lindemann, O.; Umlauf, D.; Frank, S.; Schimmelpfennig, S.; Bertrand, J.; Pap, T.; Hanley, P.J.; Fabian, A.; Dietrich, A.; Schwab, A. TRPC6 Regulates CXCR2-Mediated Chemotaxis of Murine Neutrophils. J. Immunol. 2013, 190, 5496-5505. [CrossRef] [PubMed]

25. Schaefer, M. TRPs: Modulation by drug-like compounds. Handb. Exp. Pharm. 2014, 223, 1077-1106. [CrossRef]

26. Washburn, D.G.; Holt, D.A.; Dodson, J.; McAtee, J.J.; Terrell, L.R.; Barton, L.; Manns, S.; Waszkiewicz, A.; Pritchard, C.; Gillie, D.J.; et al. The discovery of potent blockers of the canonical transient receptor channels, TRPC3 and TRPC6, based on an anilino-thiazole pharmacophore. Bioorg. Med. Chem. Lett. 2013, 23, 4979-4984. [CrossRef] [PubMed]

27. Seo, K.; Rainer, P.P.; Shalkey Hahn, V.; Lee, D.I.; Jo, S.H.; Andersen, A.; Liu, T.; Xu, X.; Willette, R.N.; Lepore, J.J.; et al. Combined TRPC3 and TRPC6 blockade by selective small-molecule or genetic deletion inhibits pathological cardiac hypertrophy. Proc. Natl. Acad. Sci. USA 2014, 111, 1551-1556. [CrossRef] [PubMed]

28. Maier, T.; Follmann, M.; Hessler, G.; Kleemann, H.W.; Hachtel, S.; Fuchs, B.; Weissmann, N.; Linz, W.; Schmidt, T.; Lohn, M.; et al. Discovery and pharmacological characterization of a novel potent inhibitor of diacylglycerol-sensitive TRPC cation channels. Br. J. Pharmacol. 2015, 172, 3650-3660. [CrossRef] [PubMed]

29. Urban, N.; Hill, K.; Wang, L.; Kuebler, W.M.; Schaefer, M. Novel pharmacological TRPC inhibitors block hypoxia-induced vasoconstriction. Cell Calcium 2012, 51, 194-206. [CrossRef] [PubMed]

30. Hafner, S.; Burg, F.; Kannler, M.; Urban, N.; Mayer, P.; Dietrich, A.; Trauner, D.; Broichhagen, J.; Schaefer, M. A (+)-Larixol Congener with High Affinity and Subtype Selectivity toward TRPC6. ChemMedChem 2018, 13, 1028-1035. [CrossRef] [PubMed]

31. Tang, Q.; Guo, W.; Zheng, L.; Wu, J.X.; Liu, M.; Zhou, X.; Zhang, X.; Chen, L. Structure of the receptor-activated human TRPC6 and TRPC3 ion channels. Cell Res. 2018, 28, 746-755. [CrossRef] [PubMed]

32. Hu, H.; Bandell, M.; Petrus, M.J.; Zhu, M.X.; Patapoutian, A. Zinc activates damage-sensing TRPA1 ion channels. Nat. Chem. Biol. 2009, 5, 183-190. [CrossRef] [PubMed]

33. Zygmunt, P.M.; Hogestatt, E.D. Trpa1. Handb. Exp. Pharm. 2014, 222, 583-630. [CrossRef]

34. Nassini, R.; Pedretti, P.; Moretto, N.; Fusi, C.; Carnini, C.; Facchinetti, F.; Viscomi, A.R.; Pisano, A.R.; Stokesberry, S.; Brunmark, C.; et al. Transient receptor potential ankyrin 1 channel localized to non-neuronal airway cells promotes non-neurogenic inflammation. PLoS ONE 2012, 7, e42454. [CrossRef] [PubMed]

35. Jaquemar, D.; Schenker, T.; Trueb, B. An ankyrin-like protein with transmembrane domains is specifically lost after oncogenic transformation of human fibroblasts. J. Biol. Chem. 1999, 274, 7325-7333. [CrossRef] [PubMed]

36. Mukhopadhyay, I.; Gomes, P.; Aranake, S.; Shetty, M.; Karnik, P.; Damle, M.; Kuruganti, S.; Thorat, S.; Khairatkar-Joshi, N. Expression of functional TRPA1 receptor on human lung fibroblast and epithelial cells. J. Recept. Signal Transduct. Res. 2011, 31, 350-358. [CrossRef] [PubMed]

37. Jang, Y.; Lee, Y.; Kim, S.M.; Yang, Y.D.; Jung, J.; Oh, U. Quantitative analysis of TRP channel genes in mouse organs. Arch. Pharm. Res. 2012, 35, 1823-1830. [CrossRef] [PubMed] 
38. Story, G.M.; Peier, A.M.; Reeve, A.J.; Eid, S.R.; Mosbacher, J.; Hricik, T.R.; Earley, T.J.; Hergarden, A.C.; Andersson, D.A.; Hwang, S.W.; et al. ANKTM1, a TRP-like channel expressed in nociceptive neurons, is activated by cold temperatures. Cell 2003, 112, 819-829. [CrossRef]

39. Jordt, S.E.; Bautista, D.M.; Chuang, H.H.; McKemy, D.D.; Zygmunt, P.M.; Hogestatt, E.D.; Meng, I.D.; Julius, D. Mustard oils and cannabinoids excite sensory nerve fibres through the TRP channel ANKTM1. Nature 2004, 427, 260-265. [CrossRef] [PubMed]

40. Caceres, A.I.; Brackmann, M.; Elia, M.D.; Bessac, B.F.; del Camino, D.; D'Amours, M.; Witek, J.S.; Fanger, C.M.; Chong, J.A.; Hayward, N.J.; et al. A sensory neuronal ion channel essential for airway inflammation and hyperreactivity in asthma. Proc. Natl. Acad. Sci. USA 2009, 106, 9099-9104. [CrossRef] [PubMed]

41. Nassenstein, C.; Kwong, K.; Taylor-Clark, T.; Kollarik, M.; Macglashan, D.M.; Braun, A.; Undem, B.J. Expression and function of the ion channel TRPA1 in vagal afferent nerves innervating mouse lungs. J. Physiol. 2008, 586, 1595-1604. [CrossRef] [PubMed]

42. Takahashi, N.; Kuwaki, T.; Kiyonaka, S.; Numata, T.; Kozai, D.; Mizuno, Y.; Yamamoto, S.; Naito, S.; Knevels, E.; Carmeliet, P.; et al. TRPA1 underlies a sensing mechanism for $\mathrm{O}_{2}$. Nat. Chem. Biol. 2011, 7, 701-711. [CrossRef] [PubMed]

43. Buch, T.R.; Schafer, E.A.; Demmel, M.T.; Boekhoff, I.; Thiermann, H.; Gudermann, T.; Steinritz, D.; Schmidt, A. Functional expression of the transient receptor potential channel TRPA1, a sensor for toxic lung inhalants, in pulmonary epithelial cells. Chem.-Biol. Interact. 2013, 206, 462-471. [CrossRef] [PubMed]

44. Kannler, M.; Luling, R.; Yildirim, A.O.; Gudermann, T.; Steinritz, D.; Dietrich, A. TRPA1 channels: Expression in non-neuronal murine lung tissues and dispensability for hyperoxia-induced alveolar epithelial hyperplasia. Pflugers Arch. 2018. [CrossRef] [PubMed]

45. Andersson, D.A.; Gentry, C.; Alenmyr, L.; Killander, D.; Lewis, S.E.; Andersson, A.; Bucher, B.; Galzi, J.L.; Sterner, O.; Bevan, S.; et al. TRPA1 mediates spinal antinociception induced by acetaminophen and the cannabinoid Delta(9)-tetrahydrocannabiorcol. Nat. Commun. 2011, 2, 551. [CrossRef] [PubMed]

46. Schulze, A.; Oehler, B.; Urban, N.; Schaefer, M.; Hill, K. Apomorphine is a bimodal modulator of TRPA1 channels. Mol. Pharmacol. 2013, 83, 542-551. [CrossRef] [PubMed]

47. Hill, K.; Schaefer, M. TRPA1 is differentially modulated by the amphipathic molecules trinitrophenol and chlorpromazine. J. Biol. Chem. 2007, 282, 7145-7153. [CrossRef] [PubMed]

48. Zhao, M.; Isami, K.; Nakamura, S.; Shirakawa, H.; Nakagawa, T.; Kaneko, S. Acute cold hypersensitivity characteristically induced by oxaliplatin is caused by the enhanced responsiveness of TRPA1 in mice. Mol. Pain 2012, 8, 55. [CrossRef] [PubMed]

49. Than, J.Y.; Li, L.; Hasan, R.; Zhang, X. Excitation and modulation of TRPA1, TRPV1, and TRPM8 channel-expressing sensory neurons by the pruritogen chloroquine. J. Biol. Chem. 2013, 288, 12818-12827. [CrossRef] [PubMed]

50. Inoue, N.; Ito, S.; Nogawa, M.; Tajima, K.; Kyoi, T. Etodolac blocks the allyl isothiocyanate-induced response in mouse sensory neurons by selective TRPA1 activation. Pharmacology 2012, 90, 47-54. [CrossRef] [PubMed]

51. Mutoh, T.; Taki, Y.; Tsubone, H. Desflurane but not sevoflurane augments laryngeal C-fiber inputs to nucleus tractus solitarii neurons by activating transient receptor potential-A1. Life Sci. 2013, 92, 821-828. [CrossRef] [PubMed]

52. Hatano, N.; Suzuki, H.; Muraki, Y.; Muraki, K. Stimulation of human TRPA1 channels by clinical concentrations of the antirheumatic drug auranofin. Am. J. Physiol. Cell Physiol. 2013, 304, C354-C361. [CrossRef] [PubMed]

53. McNamara, C.R.; Mandel-Brehm, J.; Bautista, D.M.; Siemens, J.; Deranian, K.L.; Zhao, M.; Hayward, N.J.; Chong, J.A.; Julius, D.; Moran, M.M.; et al. TRPA1 mediates formalin-induced pain. Proc. Natl. Acad. Sci. USA 2007, 104, 13525-13530. [CrossRef] [PubMed]

54. Wei, H.; Hamalainen, M.M.; Saarnilehto, M.; Koivisto, A.; Pertovaara, A. Attenuation of mechanical hypersensitivity by an antagonist of the TRPA1 ion channel in diabetic animals. Anesthesiology 2009, 111, 147-154. [CrossRef] [PubMed]

55. Petrus, M.; Peier, A.M.; Bandell, M.; Hwang, S.W.; Huynh, T.; Olney, N.; Jegla, T.; Patapoutian, A. A role of TRPA1 in mechanical hyperalgesia is revealed by pharmacological inhibition. Mol. Pain 2007, 3, 40. [CrossRef] [PubMed] 
56. McGaraughty, S.; Chu, K.L.; Perner, R.J.; Didomenico, S.; Kort, M.E.; Kym, P.R. TRPA1 modulation of spontaneous and mechanically evoked firing of spinal neurons in uninjured, osteoarthritic, and inflamed rats. Mol. Pain 2010, 6, 14. [CrossRef] [PubMed]

57. Nyman, E.; Franzen, B.; Nolting, A.; Klement, G.; Liu, G.; Nilsson, M.; Rosen, A.; Bjork, C.; Weigelt, D.; Wollberg, P.; et al. In vitro pharmacological characterization of a novel TRPA1 antagonist and proof of mechanism in a human dental pulp model. J. Pain Res. 2013, 6, 59-70. [CrossRef] [PubMed]

58. Mukhopadhyay, I.; Kulkarni, A.; Aranake, S.; Karnik, P.; Shetty, M.; Thorat, S.; Ghosh, I.; Wale, D.; Bhosale, V.; Khairatkar-Joshi, N. Transient receptor potential ankyrin 1 receptor activation in vitro and in vivo by pro-tussive agents: GRC 17536 as a promising anti-tussive therapeutic. PLoS ONE 2014, 9, e97005. [CrossRef] [PubMed]

59. Mukhopadhyay, I.; Kulkarni, A.; Khairatkar-Joshi, N. Blocking TRPA1 in Respiratory Disorders: Does It Hold a Promise? Pharmaceuticals 2016, 9, 70. [CrossRef] [PubMed]

60. Conklin, D.J.; Haberzettl, P.; Jagatheesan, G.; Kong, M.; Hoyle, G.W. Role of TRPA1 in acute cardiopulmonary toxicity of inhaled acrolein. Toxicol. Appl. Pharm. 2016, 324, 61-72. [CrossRef] [PubMed]

61. Caterina, M.J.; Schumacher, M.A.; Tominaga, M.; Rosen, T.A.; Levine, J.D.; Julius, D. The capsaicin receptor: A heat-activated ion channel in the pain pathway. Nature 1997, 389, 816-824. [CrossRef] [PubMed]

62. Bevan, S.; Quallo, T.; Andersson, D.A. Trpv1. Handb. Exp. Pharm. 2014, 222, 207-245. [CrossRef]

63. Bron, R.; Klesse, L.J.; Shah, K.; Parada, L.F.; Winter, J. Activation of Ras is necessary and sufficient for upregulation of vanilloid receptor type 1 in sensory neurons by neurotrophic factors. Mol. Cell. Neurosci. 2003, 22, 118-132. [CrossRef]

64. Winter, J. Brain derived neurotrophic factor, but not nerve growth factor, regulates capsaicin sensitivity of rat vagal ganglion neurones. Neurosci. Lett. 1998, 241, 21-24. [CrossRef]

65. Ikeda-Miyagawa, Y.; Kobayashi, K.; Yamanaka, H.; Okubo, M.; Wang, S.; Dai, Y.; Yagi, H.; Hirose, M.; Noguchi, K. Peripherally increased artemin is a key regulator of TRPA1/V1 expression in primary afferent neurons. Mol. Pain 2015, 11, 8. [CrossRef] [PubMed]

66. Jancso-Gabor, A.; Szolcsanyi, J.; Jancso, N. Stimulation and desensitization of the hypothalamic heat-sensitive structures by capsaicin in rats. J. Physiol. 1970, 208, 449-459. [CrossRef] [PubMed]

67. Hung, C.Y.; Tan, C.H. TRP Channels in Nociception and Pathological Pain. Adv. Exp. Med. Biol. 2018, 1099, 13-27. [CrossRef]

68. Vandewauw, I.; De Clercq, K.; Mulier, M.; Held, K.; Pinto, S.; Van Ranst, N.; Segal, A.; Voet, T.; Vennekens, R.; Zimmermann, K.; et al. A TRP channel trio mediates acute noxious heat sensing. Nature 2018, 555, 662-666. [CrossRef] [PubMed]

69. Fischer, M.J.; Balasuriya, D.; Jeggle, P.; Goetze, T.A.; McNaughton, P.A.; Reeh, P.W.; Edwardson, J.M. Direct evidence for functional TRPV1/TRPA1 heteromers. Pflugers Arch. 2014, 466, 2229-2241. [CrossRef] [PubMed]

70. Kark, T.; Bagi, Z.; Lizanecz, E.; Pasztor, E.T.; Erdei, N.; Czikora, A.; Papp, Z.; Edes, I.; Porszasz, R.; Toth, A. Tissue-specific regulation of microvascular diameter: Opposite functional roles of neuronal and smooth muscle located vanilloid receptor-1. Mol. Pharmacol. 2008, 73, 1405-1412. [CrossRef] [PubMed]

71. Cavanaugh, D.J.; Chesler, A.T.; Jackson, A.C.; Sigal, Y.M.; Yamanaka, H.; Grant, R.; O’'Donnell, D.; Nicoll, R.A.; Shah, N.M.; Julius, D.; et al. Trpv1 reporter mice reveal highly restricted brain distribution and functional expression in arteriolar smooth muscle cells. J. Neurosci. 2011, 31, 5067-5077. [CrossRef] [PubMed]

72. Sadofsky, L.R.; Ramachandran, R.; Crow, C.; Cowen, M.; Compton, S.J.; Morice, A.H. Inflammatory stimuli up-regulate transient receptor potential vanilloid-1 expression in human bronchial fibroblasts. Exp. Lung Res. 2012, 38, 75-81. [CrossRef] [PubMed]

73. Reilly, C.A.; Taylor, J.L.; Lanza, D.L.; Carr, B.A.; Crouch, D.J.; Yost, G.S. Capsaicinoids cause inflammation and epithelial cell death through activation of vanilloid receptors. Toxicol. Sci. Off. J. Soc. Toxicol. 2003, 73, 170-181. [CrossRef] [PubMed]

74. Reilly, C.A.; Johansen, M.E.; Lanza, D.L.; Lee, J.; Lim, J.O.; Yost, G.S. Calcium-dependent and independent mechanisms of capsaicin receptor (TRPV1)-mediated cytokine production and cell death in human bronchial epithelial cells. J. Biochem. Mol. Toxicol. 2005, 19, 266-275. [CrossRef] [PubMed]

75. Carnevale, V.; Rohacs, T. TRPV1: A Target for Rational Drug Design. Pharmaceuticals 2016, 9, 52. [CrossRef] [PubMed] 
76. Bhave, G.; Zhu, W.; Wang, H.; Brasier, D.J.; Oxford, G.S.; Gereau, R.W.T. cAMP-dependent protein kinase regulates desensitization of the capsaicin receptor (VR1) by direct phosphorylation. Neuron 2002, 35, 721-731. [CrossRef]

77. Marabini, S.; Ciabatti, P.G.; Polli, G.; Fusco, B.M.; Geppetti, P. Beneficial effects of intranasal applications of capsaicin in patients with vasomotor rhinitis. Eur. Arch. Otorhinolaryngol. 1991, 248, 191-194. [PubMed]

78. Park, C.K.; Xu, Z.Z.; Liu, T.; Lu, N.; Serhan, C.N.; Ji, R.R. Resolvin D2 is a potent endogenous inhibitor for transient receptor potential subtype $\mathrm{V} 1 / \mathrm{A} 1$, inflammatory pain, and spinal cord synaptic plasticity in mice: Distinct roles of resolvin D1, D2, and E1. J. Neurosci. 2011, 31, 18433-18438. [CrossRef] [PubMed]

79. Valenzano, K.J.; Grant, E.R.; Wu, G.; Hachicha, M.; Schmid, L.; Tafesse, L.; Sun, Q.; Rotshteyn, Y.; Francis, J.; Limberis, J.; et al. N-(4-tertiarybutylphenyl)-4-(3-chloropyridin-2-yl)tetrahydropyrazine -1(2H)-carbox-amide (BCTC), a novel, orally effective vanilloid receptor 1 antagonist with analgesic properties: I. in vitro characterization and pharmacokinetic properties. J. Pharm. Exp. 2003, 306, 377-386. [CrossRef] [PubMed]

80. Kitaguchi, T.; Swartz, K.J. An inhibitor of TRPV1 channels isolated from funnel Web spider venom. Biochemistry 2005, 44, 15544-15549. [CrossRef] [PubMed]

81. Surowy, C.S.; Neelands, T.R.; Bianchi, B.R.; McGaraughty, S.; El Kouhen, R.; Han, P.; Chu, K.L.; McDonald, H.A.; Vos, M.; Niforatos, W.; et al. (R)-(5-tert-butyl-2,3-dihydro-1H-inden-1-yl)-3-(1H-indazol4-yl)-urea (ABT-102) blocks polymodal activation of transient receptor potential vanilloid 1 receptors in vitro and heat-evoked firing of spinal dorsal horn neurons in vivo. J. Pharm. Exp. 2008, 326, 879-888. [CrossRef] [PubMed]

82. Rami, H.K.; Thompson, M.; Stemp, G.; Fell, S.; Jerman, J.C.; Stevens, A.J.; Smart, D.; Sargent, B.; Sanderson, D.; Randall, A.D.; et al. Discovery of SB-705498: A potent, selective and orally bioavailable TRPV1 antagonist suitable for clinical development. Bioorg. Med. Chem. Lett. 2006, 16, 3287-3291. [CrossRef] [PubMed]

83. Khalid, S.; Murdoch, R.; Newlands, A.; Smart, K.; Kelsall, A.; Holt, K.; Dockry, R.; Woodcock, A.; Smith, J.A. Transient receptor potential vanilloid 1 (TRPV1) antagonism in patients with refractory chronic cough: A double-blind randomized controlled trial. J. Allergy Clin. Immunol. 2014, 134, 56-62. [CrossRef] [PubMed]

84. Kelly, S.; Chapman, R.J.; Woodhams, S.; Sagar, D.R.; Turner, J.; Burston, J.J.; Bullock, C.; Paton, K.; Huang, J.; Wong, A.; et al. Increased function of pronociceptive TRPV1 at the level of the joint in a rat model of osteoarthritis pain. Ann. Rheum. Dis. 2015, 74, 252-259. [CrossRef] [PubMed]

85. Ghilardi, J.R.; Rohrich, H.; Lindsay, T.H.; Sevcik, M.A.; Schwei, M.J.; Kubota, K.; Halvorson, K.G.; Poblete, J.; Chaplan, S.R.; Dubin, A.E.; et al. Selective blockade of the capsaicin receptor TRPV1 attenuates bone cancer pain. J. Neurosci. 2005, 25, 3126-3131. [CrossRef] [PubMed]

86. Gavva, N.R.; Treanor, J.J.; Garami, A.; Fang, L.; Surapaneni, S.; Akrami, A.; Alvarez, F.; Bak, A.; Darling, M.; Gore, A.; et al. Pharmacological blockade of the vanilloid receptor TRPV1 elicits marked hyperthermia in humans. Pain 2008, 136, 202-210. [CrossRef] [PubMed]

87. Krarup, A.L.; Ny, L.; Astrand, M.; Bajor, A.; Hvid-Jensen, F.; Hansen, M.B.; Simren, M.; Funch-Jensen, P.; Drewes, A.M. Randomised clinical trial: The efficacy of a transient receptor potential vanilloid 1 antagonist AZD1386 in human oesophageal pain. Aliment. Pharm. 2011, 33, 1113-1122. [CrossRef] [PubMed]

88. Lee, Y.; Hong, S.; Cui, M.; Sharma, P.K.; Lee, J.; Choi, S. Transient receptor potential vanilloid type 1 antagonists: A patent review (2011-2014). Expert Opin. Ther. Pat. 2015, 25, 291-318. [CrossRef] [PubMed]

89. Manitpisitkul, P.; Shalayda, K.; Russell, L.; Sanga, P.; Solanki, B.; Caruso, J.; Iwaki, Y.; Moyer, J.A. Pharmacokinetics and Safety of Mavatrep (JNJ-39439335), a TRPV1 Antagonist in Healthy Japanese and Caucasian Men: A Double-Blind, Randomized, Placebo-Controlled, Sequential-Group Phase 1 Study. Clin. Pharm. Drug Dev. 2018, 7, 712-726. [CrossRef] [PubMed]

90. Manitpisitkul, P.; Shalayda, K.; Russell, L.; Sanga, P.; Williams, Y.; Solanki, B.; Caruso, J.; Moyer, J.A. Bioavailability and Pharmacokinetics of TRPV1 Antagonist Mavatrep (JNJ-39439335) Tablet and Capsule Formulations in Healthy Men: Two Open-Label, Crossover, Single-Dose Phase 1 Studies. Clin. Pharm. Drug Dev. 2018, 7, 699-711. [CrossRef] [PubMed]

91. Delescluse, I.; Mace, H.; Adcock, J.J. Inhibition of airway hyper-responsiveness by TRPV1 antagonists (SB-705498 and PF-04065463) in the unanaesthetized, ovalbumin-sensitized guinea pig. Br. J. Pharmacol. 2012, 166, 1822-1832. [CrossRef] [PubMed] 
92. Baxter, M.; Eltom, S.; Dekkak, B.; Yew-Booth, L.; Dubuis, E.D.; Maher, S.A.; Belvisi, M.G.; Birrell, M.A. Role of transient receptor potential and pannexin channels in cigarette smoke-triggered ATP release in the lung. Thorax 2014, 69, 1080-1089. [CrossRef] [PubMed]

93. Liedtke, W.; Choe, Y.; Marti-Renom, M.A.; Bell, A.M.; Denis, C.S.; Sali, A.; Hudspeth, A.J.; Friedman, J.M.; Heller, S. Vanilloid receptor-related osmotically activated channel (VR-OAC), a candidate vertebrate osmoreceptor. Cell 2000, 103, 525-535. [CrossRef]

94. Strotmann, R.; Harteneck, C.; Nunnenmacher, K.; Schultz, G.; Plant, T.D. OTRPC4, a nonselective cation channel that confers sensitivity to extracellular osmolarity. Nat. Cell Biol. 2000, 2, 695-702. [CrossRef] [PubMed]

95. Wissenbach, U.; Bodding, M.; Freichel, M.; Flockerzi, V. Trp12, a novel Trp related protein from kidney. FEBS Lett. 2000, 485, 127-134. [CrossRef]

96. Guler, A.D.; Lee, H.; Iida, T.; Shimizu, I.; Tominaga, M.; Caterina, M. Heat-evoked activation of the ion channel, TRPV4. J. Neurosci. 2002, 22, 6408-6414. [CrossRef] [PubMed]

97. Loukin, S.; Zhou, X.; Su, Z.; Saimi, Y.; Kung, C. Wild-type and brachyolmia-causing mutant TRPV4 channels respond directly to stretch force. J. Biol. Chem. 2010, 285, 27176-27181. [CrossRef] [PubMed]

98. Garcia-Elias, A.; Mrkonjic, S.; Jung, C.; Pardo-Pastor, C.; Vicente, R.; Valverde, M.A. The TRPV4 channel. Handb. Exp. Pharm. 2014, 222, 293-319. [CrossRef]

99. Everaerts, W.; Vriens, J.; Owsianik, G.; Appendino, G.; Voets, T.; De Ridder, D.; Nilius, B. Functional characterization of transient receptor potential channels in mouse urothelial cells. Am. J. Physiol. Renal Physiol. 2010, 298, F692-F701. [CrossRef] [PubMed]

100. Denda, M.; Fuziwara, S.; Inoue, K.; Denda, S.; Akamatsu, H.; Tomitaka, A.; Matsunaga, K. Immunoreactivity of VR1 on epidermal keratinocyte of human skin. Biochem. Biophys. Res. Commun. 2001, 285, 1250-1252. [CrossRef] [PubMed]

101. Simmons, S.; Erfinanda, L.; Bartz, C.; Kuebler, W.M. Novel mechanisms regulating endothelial barrier function in the pulmonary microcirculation. J. Physiol. 2018. [CrossRef] [PubMed]

102. Bagher, P.; Beleznai, T.; Kansui, Y.; Mitchell, R.; Garland, C.J.; Dora, K.A. Low intravascular pressure activates endothelial cell TRPV4 channels, local $\mathrm{Ca}^{2+}$ events, and IKCa channels, reducing arteriolar tone. Proc. Natl. Acad. Sci. USA 2012, 109, 18174-18179. [CrossRef] [PubMed]

103. Fernandez-Fernandez, J.M.; Andrade, Y.N.; Arniges, M.; Fernandes, J.; Plata, C.; Rubio-Moscardo, F.; Vazquez, E.; Valverde, M.A. Functional coupling of TRPV4 cationic channel and large conductance, calcium-dependent potassium channel in human bronchial epithelial cell lines. Pflugers Arch. 2008, 457, 149-159. [CrossRef] [PubMed]

104. Jia, Y.; Wang, X.; Varty, L.; Rizzo, C.A.; Yang, R.; Correll, C.C.; Phelps, P.T.; Egan, R.W.; Hey, J.A. Functional TRPV4 channels are expressed in human airway smooth muscle cells. Am. J. Physiol. Lung Cell. Mol. Physiol. 2004, 287, L272-L278. [CrossRef] [PubMed]

105. Lorenzo, I.M.; Liedtke, W.; Sanderson, M.J.; Valverde, M.A. TRPV4 channel participates in receptor-operated calcium entry and ciliary beat frequency regulation in mouse airway epithelial cells. Proc. Natl. Acad. Sci. USA 2008, 105, 12611-12616. [CrossRef] [PubMed]

106. Xia, Y.; Fu, Z.; Hu, J.; Huang, C.; Paudel, O.; Cai, S.; Liedtke, W.; Sham, J.S. TRPV4 channel contributes to serotonin-induced pulmonary vasoconstriction and the enhanced vascular reactivity in chronic hypoxic pulmonary hypertension. Am. J. Physiol. Cell Physiol. 2013, 305, C704-C715. [CrossRef] [PubMed]

107. Alvarez, D.F.; King, J.A.; Weber, D.; Addison, E.; Liedtke, W.; Townsley, M.I. Transient receptor potential vanilloid 4-mediated disruption of the alveolar septal barrier: A novel mechanism of acute lung injury. Circ. Res. 2006, 99, 988-995. [CrossRef] [PubMed]

108. Hamanaka, K.; Jian, M.Y.; Townsley, M.I.; King, J.A.; Liedtke, W.; Weber, D.S.; Eyal, F.G.; Clapp, M.M.; Parker, J.C. TRPV4 channels augment macrophage activation and ventilator-induced lung injury. Am. J. Physiol. Lung Cell. Mol. Physiol. 2010, 299, L353-L362. [CrossRef] [PubMed]

109. Goldenberg, N.M.; Ravindran, K.; Kuebler, W.M. TRPV4: Physiological role and therapeutic potential in respiratory diseases. Naunyn Schmiedebergs Arch. Pharm. 2015, 388, 421-436. [CrossRef] [PubMed]

110. Akazawa, Y.; Yuki, T.; Yoshida, H.; Sugiyama, Y.; Inoue, S. Activation of TRPV4 strengthens the tight-junction barrier in human epidermal keratinocytes. Ski. Pharm. Physiol. 2013, 26, 15-21. [CrossRef] [PubMed] 
111. Janssen, D.A.; Jansen, C.J.; Hafmans, T.G.; Verhaegh, G.W.; Hoenderop, J.G.; Heesakkers, J.P.; Schalken, J.A. TRPV4 channels in the human urogenital tract play a role in cell junction formation and epithelial barrier. Acta Physiol. 2016, 218, 38-48. [CrossRef] [PubMed]

112. Martinez-Rendon, J.; Sanchez-Guzman, E.; Rueda, A.; Gonzalez, J.; Gulias-Canizo, R.; Aquino-Jarquin, G.; Castro-Munozledo, F.; Garcia-Villegas, R. TRPV4 Regulates Tight Junctions and Affects Differentiation in a Cell Culture Model of the Corneal Epithelium. J. Cell. Physiol. 2017, 232, 1794-1807. [CrossRef] [PubMed]

113. Klausen, T.K.; Pagani, A.; Minassi, A.; Ech-Chahad, A.; Prenen, J.; Owsianik, G.; Hoffmann, E.K.; Pedersen, S.F.; Appendino, G.; Nilius, B. Modulation of the transient receptor potential vanilloid channel TRPV4 by 4alpha-phorbol esters: A structure-activity study. J. Med. Chem. 2009, 52, 2933-2939. [CrossRef] [PubMed]

114. Watanabe, H.; Vriens, J.; Prenen, J.; Droogmans, G.; Voets, T.; Nilius, B. Anandamide and arachidonic acid use epoxyeicosatrienoic acids to activate TRPV4 channels. Nature 2003, 424, 434-438. [CrossRef] [PubMed]

115. Smith, P.L.; Maloney, K.N.; Pothen, R.G.; Clardy, J.; Clapham, D.E. Bisandrographolide from Andrographis paniculata activates TRPV4 channels. J. Biol. Chem. 2006, 281, 29897-29904. [CrossRef] [PubMed]

116. Willette, R.N.; Bao, W.; Nerurkar, S.; Yue, T.L.; Doe, C.P.; Stankus, G.; Turner, G.H.; Ju, H.; Thomas, H.; Fishman, C.E.; et al. Systemic activation of the transient receptor potential vanilloid subtype 4 channel causes endothelial failure and circulatory collapse: Part 2. J. Pharm. Exp. 2008, 326, 443-452. [CrossRef] [PubMed]

117. Thorneloe, K.S.; Sulpizio, A.C.; Lin, Z.; Figueroa, D.J.; Clouse, A.K.; McCafferty, G.P.; Chendrimada, T.P.; Lashinger, E.S.; Gordon, E.; Evans, L.; et al. N-((1S)-1-\{[4-((2S)-2-\{[(2,4-dichlorophenyl)sulfonyl]amino\}-3hydroxypropanoyl)-1-piperazinyl]carbonyl\}-3-methylbutyl)-1-benzothiophene-2-carboxamide (GSK1016790A), a novel and potent transient receptor potential vanilloid 4 channel agonist induces urinary bladder contraction and hyperactivity: Part I. J. Pharm. Exp. 2008, 326, 432-442. [CrossRef]

118. Vincent, F.; Acevedo, A.; Nguyen, M.T.; Dourado, M.; DeFalco, J.; Gustafson, A.; Spiro, P.; Emerling, D.E.; Kelly, M.G.; Duncton, M.A. Identification and characterization of novel TRPV4 modulators. Biochem. Biophys. Res. Commun. 2009, 389, 490-494. [CrossRef] [PubMed]

119. Phan, M.N.; Leddy, H.A.; Votta, B.J.; Kumar, S.; Levy, D.S.; Lipshutz, D.B.; Lee, S.H.; Liedtke, W.; Guilak, F. Functional characterization of TRPV4 as an osmotically sensitive ion channel in porcine articular chondrocytes. Arthritis Rheumatol. 2009, 60, 3028-3037. [CrossRef] [PubMed]

120. Everaerts, W.; Zhen, X.; Ghosh, D.; Vriens, J.; Gevaert, T.; Gilbert, J.P.; Hayward, N.J.; McNamara, C.R.; Xue, F.; Moran, M.M.; et al. Inhibition of the cation channel TRPV4 improves bladder function in mice and rats with cyclophosphamide-induced cystitis. Proc. Natl. Acad. Sci. USA 2010, 107, 19084-19089. [CrossRef] [PubMed]

121. Thorneloe, K.S.; Cheung, M.; Bao, W.; Alsaid, H.; Lenhard, S.; Jian, M.Y.; Costell, M.; Maniscalco-Hauk, K.; Krawiec, J.A.; Olzinski, A.; et al. An orally active TRPV4 channel blocker prevents and resolves pulmonary edema induced by heart failure. Sci. Transl. Med. 2012, 4, 159ra148. [CrossRef] [PubMed]

122. Huh, D.; Leslie, D.C.; Matthews, B.D.; Fraser, J.P.; Jurek, S.; Hamilton, G.A.; Thorneloe, K.S.; McAlexander, M.A.; Ingber, D.E. A human disease model of drug toxicity-induced pulmonary edema in a lung-on-a-chip microdevice. Sci. Transl. Med. 2012, 4, 159ra147. [CrossRef] [PubMed]

123. Sel, S.; Rost, B.R.; Yildirim, A.O.; Sel, B.; Kalwa, H.; Fehrenbach, H.; Renz, H.; Gudermann, T.; Dietrich, A. Loss of classical transient receptor potential 6 channel reduces allergic airway response. Clin. Exp. Allergy 2008, 38, 1548-1558. [CrossRef] [PubMed]

124. McGarvey, L.P.; Butler, C.A.; Stokesberry, S.; Polley, L.; McQuaid, S.; Abdullah, H.; Ashraf, S.; McGahon, M.K.; Curtis, T.M.; Arron, J.; et al. Increased expression of bronchial epithelial transient receptor potential vanilloid 1 channels in patients with severe asthma. J. Allergy Clin. Immunol. 2014, 133, 704-712. [CrossRef] [PubMed]

125. Balakrishna, S.; Song, W.; Achanta, S.; Doran, S.F.; Liu, B.; Kaelberer, M.M.; Yu, Z.; Sui, A.; Cheung, M.; Leishman, E.; et al. TRPV4 inhibition counteracts edema and inflammation and improves pulmonary function and oxygen saturation in chemically induced acute lung injury. Am. J. Physiol. Lung Cell. Mol. Physiol. 2014, 307, L158-L172. [CrossRef] [PubMed]

126. Fantozzi, I.; Zhang, S.; Platoshyn, O.; Remillard, C.V.; Cowling, R.T.; Yuan, J.X. Hypoxia increases AP-1 binding activity by enhancing capacitative Ca2+ entry in human pulmonary artery endothelial cells. Am. J. Physiol. Lung Cell. Mol. Physiol. 2003, 285, L1233-L1245. [CrossRef] [PubMed] 
127. Wang, Y.X.; Wang, J.; Wang, C.; Liu, J.; Shi, L.P.; Xu, M.; Wang, C. Functional expression of transient receptor potential vanilloid-related channels in chronically hypoxic human pulmonary arterial smooth muscle cells. J. Membr. Biol. 2008, 223, 151-159. [CrossRef] [PubMed]

128. Rahaman, S.O.; Grove, L.M.; Paruchuri, S.; Southern, B.D.; Abraham, S.; Niese, K.A.; Scheraga, R.G.; Ghosh, S.; Thodeti, C.K.; Zhang, D.X.; et al. TRPV4 mediates myofibroblast differentiation and pulmonary fibrosis in mice. J. Clin. Investig. 2014, 124, 5225-5238. [CrossRef] [PubMed]

129. Riordan, J.R. The cystic fibrosis transmembrane conductance regulator. Annu. Rev. Physiol. 1993, 55, 609-630. [CrossRef] [PubMed]

130. Borowitz, D. CFTR, bicarbonate, and the pathophysiology of cystic fibrosis. Pediatr. Pulmonol. 2015, 50 (Suppl. 40), S24-S30. [CrossRef]

131. Prandini, P.; De Logu, F.; Fusi, C.; Provezza, L.; Nassini, R.; Montagner, G.; Materazzi, S.; Munari, S.; Gilioli, E.; Bezzerri, V.; et al. Transient Receptor Potential Ankyrin 1 Channels Modulate Inflammatory Response in Respiratory Cells from Patients with Cystic Fibrosis. Am. J. Respir. Cell Mol. Biol. 2016, 55, 645-656. [CrossRef] [PubMed]

132. Antigny, F.; Norez, C.; Dannhoffer, L.; Bertrand, J.; Raveau, D.; Corbi, P.; Jayle, C.; Becq, F.; Vandebrouck, C. Transient receptor potential canonical channel 6 links $\mathrm{Ca}^{2+}$ mishandling to cystic fibrosis transmembrane conductance regulator channel dysfunction in cystic fibrosis. Am. J. Respir. Cell Mol. Biol. 2011, 44, 83-90. [CrossRef] [PubMed]

133. Rieber, N.; Hector, A.; Carevic, M.; Hartl, D. Current concepts of immune dysregulation in cystic fibrosis. Int. J. Biochem. Cell Biol. 2014, 52, 108-112. [CrossRef] [PubMed]

134. Witko-Sarsat, V. Neutrophils in the innate immunity conundrum of cystic fibrosis: A CFTR-related matter? J. Innate Immun. 2013, 5, 195-196. [CrossRef] [PubMed]

135. Byrne, A.J.; Mathie, S.A.; Gregory, L.G.; Lloyd, C.M. Pulmonary macrophages: Key players in the innate defence of the airways. Thorax 2015, 70, 1189-1196. [CrossRef] [PubMed]

136. Di, A.; Brown, M.E.; Deriy, L.V.; Li, C.; Szeto, F.L.; Chen, Y.; Huang, P.; Tong, J.; Naren, A.P.; Bindokas, V.; et al. CFTR regulates phagosome acidification in macrophages and alters bactericidal activity. Nat. Cell Biol. 2006, 8, 933-944. [CrossRef] [PubMed]

137. Del Porto, P.; Cifani, N.; Guarnieri, S.; Di Domenico, E.G.; Mariggio, M.A.; Spadaro, F.; Guglietta, S.; Anile, M.; Venuta, F.; Quattrucci, S.; et al. Dysfunctional CFTR alters the bactericidal activity of human macrophages against Pseudomonas aeruginosa. PLoS ONE 2011, 6, e19970. [CrossRef]

138. Hayes, E.; Pohl, K.; McElvaney, N.G.; Reeves, E.P. The cystic fibrosis neutrophil: A specialized yet potentially defective cell. Arch. Immunol. Exp. 2011, 59, 97-112. [CrossRef] [PubMed]

139. Norez, C.; Vandebrouck, C.; Bertrand, J.; Noel, S.; Durieu, E.; Oumata, N.; Galons, H.; Antigny, F.; Chatelier, A.; Bois, P.; et al. Roscovitine is a proteostasis regulator that corrects the trafficking defect of F508del-CFTR by a CDK-independent mechanism. Br. J. Pharmacol. 2014, 171, 4831-4849. [CrossRef] [PubMed]

140. Riazanski, V.; Gabdoulkhakova, A.G.; Boynton, L.S.; Eguchi, R.R.; Deriy, L.V.; Hogarth, D.K.; Loaec, N.; Oumata, N.; Galons, H.; Brown, M.E.; et al. TRPC6 channel translocation into phagosomal membrane augments phagosomal function. Proc. Natl. Acad. Sci. USA 2015, 112, E6486-E6495. [CrossRef] [PubMed]

141. Meijer, L.; Nelson, D.J.; Riazanski, V.; Gabdoulkhakova, A.G.; Hery-Arnaud, G.; Le Berre, R.; Loaec, N.; Oumata, N.; Galons, H.; Nowak, E.; et al. Modulating Innate and Adaptive Immunity by (R)-Roscovitine: Potential Therapeutic Opportunity in Cystic Fibrosis. J. Innate Immun. 2016, 8, 330-349. [CrossRef] [PubMed]

142. Arniges, M.; Vazquez, E.; Fernandez-Fernandez, J.M.; Valverde, M.A. Swelling-activated Ca ${ }^{2+}$ entry via TRPV4 channel is defective in cystic fibrosis airway epithelia. J. Biol. Chem. 2004, 279, 54062-54068. [CrossRef] [PubMed]

143. Lemanske, R.F., Jr.; Busse, W.W. 6. Asthma. J. Allergy Clin. Immunol. 2003, 111, S502-S519. [CrossRef] [PubMed]

144. Kenyon, N.J.; Morrissey, B.M.; Schivo, M.; Albertson, T.E. Occupational asthma. Clin. Rev. Allergy Immunol. 2012, 43, 3-13. [CrossRef] [PubMed]

145. Bateman, E.D.; Hurd, S.S.; Barnes, P.J.; Bousquet, J.; Drazen, J.M.; FitzGerald, M.; Gibson, P.; Ohta, K.; O'Byrne, P.; Pedersen, S.E.; et al. Global strategy for asthma management and prevention: GINA executive summary. Eur. Respir. J. 2008, 31, 143-178. [CrossRef] [PubMed] 
146. Barnes, P.J. Corticosteroid resistance in patients with asthma and chronic obstructive pulmonary disease. J. Allergy Clin. Immunol. 2013, 131, 636-645. [CrossRef] [PubMed]

147. Hox, V.; Vanoirbeek, J.A.; Alpizar, Y.A.; Voedisch, S.; Callebaut, I.; Bobic, S.; Sharify, A.; De Vooght, V.; Van Gerven, L.; Devos, F.; et al. Crucial role of transient receptor potential ankyrin 1 and mast cells in induction of nonallergic airway hyperreactivity in mice. Am. J. Respir. Crit. Care Med. 2013, 187, 486-493. [CrossRef] [PubMed]

148. Dietrich, A.; Mederos y Schnitzler, M.; Emmel, J.; Kalwa, H.; Hofmann, T.; Gudermann, T. N-linked protein glycosylation is a major determinant for basal TRPC3 and TRPC6 channel activity. J. Biol. Chem. 2003, 278, 47842-47852. [CrossRef] [PubMed]

149. Song, T.; Zheng, Y.M.; Vincent, P.A.; Cai, D.; Rosenberg, P.; Wang, Y.X. Canonical transient receptor potential 3 channels activate NF-kappaB to mediate allergic airway disease via PKC-alpha/IkappaB-alpha and calcineurin/IkappaB-beta pathways. FASEB J. 2016, 30, 214-229. [CrossRef] [PubMed]

150. Wang, L.; Li, J.; Zhang, J.; He, Q.; Weng, X.; Huang, Y.; Guan, M.; Qiu, C. Inhibition of TRPC3 downregulates airway hyperresponsiveness, remodeling of OVA-sensitized mouse. Biochem. Biophys. Res. Commun. 2017, 484, 209-217. [CrossRef] [PubMed]

151. Cantero-Recasens, G.; Gonzalez, J.R.; Fandos, C.; Duran-Tauleria, E.; Smit, L.A.; Kauffmann, F.; Anto, J.M.; Valverde, M.A. Loss of function of transient receptor potential vanilloid 1 (TRPV1) genetic variant is associated with lower risk of active childhood asthma. J. Biol. Chem. 2010, 285, 27532-27535. [CrossRef] [PubMed]

152. Rogerio, A.P.; Andrade, E.L.; Calixto, J.B. C-fibers, but not the transient potential receptor vanilloid 1 (TRPV1), play a role in experimental allergic airway inflammation. Eur. J. Pharm. 2011, 662, 55-62. [CrossRef] [PubMed]

153. Malczyk, M.; Erb, A.; Veith, C.; Ghofrani, H.A.; Schermuly, R.T.; Gudermann, T.; Dietrich, A.; Weissmann, N.; Sydykov, A. The Role of Transient Receptor Potential Channel 6 Channels in the Pulmonary Vasculature. Front. Immunol. 2017, 8, 707. [CrossRef] [PubMed]

154. Humbert, M.; Lau, E.M.; Montani, D.; Jais, X.; Sitbon, O.; Simonneau, G. Advances in therapeutic interventions for patients with pulmonary arterial hypertension. Circulation 2014, 130, 2189-2208. [CrossRef] [PubMed]

155. Xia, Y.; Yang, X.R.; Fu, Z.; Paudel, O.; Abramowitz, J.; Birnbaumer, L.; Sham, J.S. Classical transient receptor potential 1 and 6 contribute to hypoxic pulmonary hypertension through differential regulation of pulmonary vascular functions. Hypertension 2014, 63, 173-180. [CrossRef] [PubMed]

156. Smith, K.A.; Voiriot, G.; Tang, H.; Fraidenburg, D.R.; Song, S.; Yamamura, H.; Yamamura, A.; Guo, Q.; Wan, J.; Pohl, N.M.; et al. Notch Activation of $\mathrm{Ca}(2+)$ Signaling in the Development of Hypoxic Pulmonary Vasoconstriction and Pulmonary Hypertension. Am. J. Respir. Cell Mol. Biol. 2015, 53, 355-367. [CrossRef] [PubMed]

157. Tabeling, C.; Yu, H.; Wang, L.; Ranke, H.; Goldenberg, N.M.; Zabini, D.; Noe, E.; Krauszman, A.; Gutbier, B.; Yin, J.; et al. CFTR and sphingolipids mediate hypoxic pulmonary vasoconstriction. Proc. Natl. Acad. Sci. USA 2015, 112, E1614-E1623. [CrossRef] [PubMed]

158. Yu, Y.; Fantozzi, I.; Remillard, C.V.; Landsberg, J.W.; Kunichika, N.; Platoshyn, O.; Tigno, D.D.; Thistlethwaite, P.A.; Rubin, L.J.; Yuan, J.X. Enhanced expression of transient receptor potential channels in idiopathic pulmonary arterial hypertension. Proc. Natl. Acad. Sci. USA 2004, 101, 13861-13866. [CrossRef] [PubMed]

159. Yu, Y.; Keller, S.H.; Remillard, C.V.; Safrina, O.; Nicholson, A.; Zhang, S.L.; Jiang, W.; Vangala, N.; Landsberg, J.W.; Wang, J.Y.; et al. A functional single-nucleotide polymorphism in the TRPC6 gene promoter associated with idiopathic pulmonary arterial hypertension. Circulation 2009, 119, 2313-2322. [CrossRef] [PubMed]

160. Savai, R.; Pullamsetti, S.S.; Kolbe, J.; Bieniek, E.; Voswinckel, R.; Fink, L.; Scheed, A.; Ritter, C.; Dahal, B.K.; Vater, A.; et al. Immune and inflammatory cell involvement in the pathology of idiopathic pulmonary arterial hypertension. Am. J. Respir. Crit. Care Med. 2012, 186, 897-908. [CrossRef] [PubMed]

161. Yang, X.R.; Lin, A.H.; Hughes, J.M.; Flavahan, N.A.; Cao, Y.N.; Liedtke, W.; Sham, J.S. Upregulation of osmo-mechanosensitive TRPV4 channel facilitates chronic hypoxia-induced myogenic tone and pulmonary hypertension. Am. J. Physiol. Lung Cell. Mol. Physiol. 2012, 302, L555-L568. [CrossRef] [PubMed] 
162. Goldenberg, N.M.; Wang, L.; Ranke, H.; Liedtke, W.; Tabuchi, A.; Kuebler, W.M. TRPV4 Is Required for Hypoxic Pulmonary Vasoconstriction. Anesthesiology 2015, 122, 1338-1348. [CrossRef] [PubMed]

163. Santo Tomas, L.H. Emphysema and chronic obstructive pulmonary disease in coal miners. Curr. Opin. Pulm. Med. 2011, 17, 123-125. [CrossRef] [PubMed]

164. Sethi, J.M.; Rochester, C.L. Smoking and chronic obstructive pulmonary disease. Clin. Chest Med. 2000, 21,67-86. [CrossRef]

165. Salvi, S.S.; Barnes, P.J. Chronic obstructive pulmonary disease in non-smokers. Lancet 2009, 374, 733-743. [CrossRef]

166. Pedersen, F.; Marwitz, S.; Holz, O.; Kirsten, A.; Bahmer, T.; Waschki, B.; Magnussen, H.; Rabe, K.F.; Goldmann, T.; Uddin, M.; et al. Neutrophil extracellular trap formation and extracellular DNA in sputum of stable COPD patients. Respir. Med. 2015, 109, 1360-1362. [CrossRef] [PubMed]

167. Belvisi, M.G.; Birrell, M.A.; Khalid, S.; Wortley, M.A.; Dockry, R.; Coote, J.; Holt, K.; Dubuis, E.; Kelsall, A.; Maher, S.A.; et al. Neurophenotypes in Airway Diseases. Insights from Translational Cough Studies. Am. J. Respir. Crit. Care Med. 2016, 193, 1364-1372. [CrossRef] [PubMed]

168. Zhu, G.; Gulsvik, A.; Bakke, P.; Ghatta, S.; Anderson, W.; Lomas, D.A.; Silverman, E.K.; Pillai, S.G. Association of TRPV4 gene polymorphisms with chronic obstructive pulmonary disease. Hum. Mol. Genet. 2009, 18, 2053-2062. [CrossRef] [PubMed]

169. Matsumoto, K.; Taki, F.; Kondoh, Y.; Taniguchi, H.; Takagi, K. Platelet-activating factor in bronchoalveolar lavage fluid of patients with adult respiratory distress syndrome. Clin. Exp. Pharm. Physiol. 1992, 19, 509-515. [CrossRef]

170. De Perrot, M.; Liu, M.; Waddell, T.K.; Keshavjee, S. Ischemia-reperfusion-induced lung injury. Am. J. Respir. Crit. Care Med. 2003, 167, 490-511. [CrossRef] [PubMed]

171. Samapati, R.; Yang, Y.; Yin, J.; Stoerger, C.; Arenz, C.; Dietrich, A.; Gudermann, T.; Adam, D.; Wu, S.; Freichel, M.; et al. Lung endothelial $\mathrm{Ca}^{2+}$ and permeability response to platelet-activating factor is mediated by acid sphingomyelinase and transient receptor potential classical 6. Am. J. Respir. Crit. Care Med. 2012, 185, 160-170. [CrossRef] [PubMed]

172. Tauseef, M.; Knezevic, N.; Chava, K.R.; Smith, M.; Sukriti, S.; Gianaris, N.; Obukhov, A.G.; Vogel, S.M.; Schraufnagel, D.E.; Dietrich, A.; et al. TLR4 activation of TRPC6-dependent calcium signaling mediates endotoxin-induced lung vascular permeability and inflammation. J. Exp. Med. 2012, 209, 1953-1968. [CrossRef] [PubMed]

173. Alpizar, Y.A.; Boonen, B.; Sanchez, A.; Jung, C.; Lopez-Requena, A.; Naert, R.; Steelant, B.; Luyts, K.; Plata, C.; De Vooght, V.; et al. TRPV4 activation triggers protective responses to bacterial lipopolysaccharides in airway epithelial cells. Nat. Commun. 2017, 8, 1059. [CrossRef] [PubMed]

174. Jian, M.Y.; King, J.A.; Al-Mehdi, A.B.; Liedtke, W.; Townsley, M.I. High vascular pressure-induced lung injury requires P450 epoxygenase-dependent activation of TRPV4. Am. J. Respir. Cell Mol. Biol. 2008, 38, 386-392. [CrossRef] [PubMed]

175. Yin, J.; Michalick, L.; Tang, C.; Tabuchi, A.; Goldenberg, N.; Dan, Q.; Awwad, K.; Wang, L.; Erfinanda, L.; Nouailles, G.; et al. Role of Transient Receptor Potential Vanilloid 4 in Neutrophil Activation and Acute Lung Injury. Am. J. Respir. Cell Mol. Biol. 2016, 54, 370-383. [CrossRef] [PubMed]

176. Kuebler, W.M.; Ying, X.; Bhattacharya, J. Pressure-induced endothelial $\mathrm{Ca}(2+)$ oscillations in lung capillaries. Am. J. Physiol. Lung Cell. Mol. Physiol. 2002, 282, L917-L923. [CrossRef] [PubMed]

177. Kuebler, W.M.; Uhlig, U.; Goldmann, T.; Schael, G.; Kerem, A.; Exner, K.; Martin, C.; Vollmer, E.; Uhlig, S. Stretch activates nitric oxide production in pulmonary vascular endothelial cells in situ. Am. J. Respir. Crit. Care Med. 2003, 168, 1391-1398. [CrossRef] [PubMed]

178. Wu, S.; Jian, M.Y.; Xu, Y.C.; Zhou, C.; Al-Mehdi, A.B.; Liedtke, W.; Shin, H.S.; Townsley, M.I. Ca ${ }^{2+}$ entry via alpha1G and TRPV4 channels differentially regulates surface expression of P-selectin and barrier integrity in pulmonary capillary endothelium. Am. J. Physiol. Lung Cell. Mol. Physiol. 2009, 297, L650-L657. [CrossRef] [PubMed]

179. Wandall-Frostholm, C.; Dalsgaard, T.; Bajoriunas, V.; Olivan-Viguera, A.; Sadda, V.; Beck, L.; Mogensen, S.; Stankevicius, E.; Simonsen, U.; Kohler, R. Genetic deficit of KCa 3.1 channels protects against pulmonary circulatory collapse induced by TRPV4 channel activation. Br. J. Pharmacol. 2015, 172, 4493-4505. [CrossRef] [PubMed] 
180. Simonsen, U.; Wandall-Frostholm, C.; Olivan-Viguera, A.; Kohler, R. Emerging roles of calcium-activated $\mathrm{K}$ channels and TRPV4 channels in lung oedema and pulmonary circulatory collapse. Acta Physiol. 2017, 219, 176-187. [CrossRef] [PubMed]

181. King, T.E., Jr.; Pardo, A.; Selman, M. Idiopathic pulmonary fibrosis. Lancet 2011, 378, 1949-1961. [CrossRef]

(C) 2019 by the author. Licensee MDPI, Basel, Switzerland. This article is an open access article distributed under the terms and conditions of the Creative Commons Attribution (CC BY) license (http:/ / creativecommons.org/licenses/by/4.0/). 